\title{
Reformas, acciones y planteamientos de rechazo a los superiores masculinos en beaterios y conventos de Toledo (siglos XV al XVII)
}

\section{Reforms, actions and rejection of male superiors in beaterios and convents of Toledo (XV-XVII)}

\author{
Laura CANABAL RodRíGuez \\ Investigadora independiente \\ laura_canabal@yahoo.es
}

Fecha de recepción: 18-04-2018

Fecha de aceptación: 09-12-2018

\begin{abstract}
RESUMEN
Los monasterios femeninos nacen en beaterios en muchos casos. Así los beaterios son el primer paso de la reclusión pero, al mismo tiempo el modelo de rechazo. Por otro lado, con el Concilio de Trento, la Contrarreforma fue la imposición de la reforma religiosa con una renovación espiritual, pero reproduce la subordinación femenina y la clausura. Nuevamente se renuevan los rechazos en este caso el modelo son los conventos de Toledo y el monasterio de San Clemente. Este estudio examina la importancia de los beaterios en las fundaciones conventuales en Toledo. Y analiza la oposición y acciones de rechazo de las beatas y monjas de las distintas comunidades monásticas y mendicantes frente a las reformas de vida claustral, incluido la normativa del Concilio de Trento. Utilizando para ello las fuentes documentales localizadas durante la elaboración de mi tesis doctoral.
\end{abstract}

PALABRAS CLAVE: Beaterios, conventos, oposición, Toledo, Edad Moderna

\section{ABSTRACT}

Women's monasteries often began as beatorios. These beaterios were thus the first step in confinement but at the same time the model of rejection. Meanwhile the Council of Trent and Counterreformation represented the imposition of religious reform with spiritual renewal, but reproduced female subordination and cloister. Again renew rejects in this case the model are convents in Toledo and the monastery of Saint Clemens. This study examines the importance of beaterios in the founding of convents in Toledo. And it analyses how pious women and nuns of the different monastic and mendicant orders opposed and rejected resist reforms of cloistered life, including the Council of Trent legislation. Using to this end documents studied during the preparation of my doctoral thesis.

KEY WORDS: Beaterios convents, opposition, Toledo, Modern Age. 


\section{INTRODUCCIÓN}

La historiografía de la Historia de la Iglesia optó con vehemente preferencia por el clero y las instituciones eclesiásticas tanto en sus investigaciones de la Edad Media como Moderna. Menor es la historiografía de las órdenes de vida regular y mucho más reducido aun el análisis de la mujer en la vida religiosa. Si bien se ha producido un cambio durante las últimas décadas, cuando el estudio de la mujer como sujeto histórico ha desarrollado ámbitos de estudio, antes inexistentes, permitiendo ampliar nuestros conocimientos entre otros de la problemática entorno a las monjas y beatas en el mundo de la vida regular. Al mismo tiempo, que las dificultades planteadas a los objetivos del Concilio de Trento (15451563), en cuanto a la clausura femenina desde diversas perspectivas de análisis.

La implantación de las ramas femeninas de las órdenes religiosas ha dado lugar a un interesante proceso de fundaciones a lo largo de un extenso periodo temporal. No obstante, en dicho desarrollo cabe tener en cuenta la influencia de unas agrupaciones características de la religiosidad femenina, originada en los enclaves urbanos desde la etapa medieval. Las agrupaciones de beatas, beaterios o incluso las beatas independientes son en una gran mayoría el origen de la fundación de un convento. Hay que hacer hincapié en este aspecto de la vida religiosa femenina, aquellas mujeres no deben considerarse simplemente un estadio inicial de algunas comunidades, especialmente cuando nos centramos en las comunidades mendicantes. Son, por tanto, un punto de partida que no cabría desdeñar por parte de la historiografía de la vida religiosa femenina.

Resulta, por tanto, fundamental conocer las intenciones de las mujeres que formaban los beaterios, pues si bien queda claro que la jerarquía de la Iglesia tiene bien delimitados sus objetivos -aquello que pasan por incluirlas dentro de la Iglesia en las ramas segundas o terceras dependiendo de la orden de la cual hablemos- ante su afán reglamentista. Los ideales e intenciones de las mujeres fueron en numerosas ocasiones muy distintos. El papel jugado por ellas se basaba en unos destacados deseos de alejarse de la vivencia religiosa establecida y prefijada por la Iglesia, tratando de autoafirmarse. Lo que evidencia cómo los procesos de rechazo que veremos en la Edad Moderna contra el Concilio de Trento hay que considerarlos activados con anterioridad. Deben estudiarse en periodos precedentes, valorando situaciones de resistencia generadas en diversos momentos de los siglos XIV y XV. Es decir, que desde los orígenes de la vida religiosa femenina, aquellas beatas bajomedievales trataron de evitar la institucionalización dentro de la vida regular, con pocos frutos eso sí, hay ya entonces intentos de rechazo y de enfrentamiento con la Iglesia y la sociedad en que estaban cobijadas.

Es por ello, que el panorama historiográfico necesita cambiar en cierta medida la visión, por así decirlo, completamente clásica, de la facilidad no solo de la aplicación de los postulados de Trento en la vida regular femenina; sino también, de los rechazos existentes desde los inicios de la vida regular para las ramas segundas y terceras. La polémica estaba servida, no fue todo tan simple.

Partiendo de ahí, la censura o tal vez sería mejor afirmar los impedimentos, no eran simplemente de carácter económico o religioso fueron también sociales. Las primeras beatas hacían frente común para vivir un modelo de religiosidad independiente que muchas de ellas trataron de mantener fuera de la Iglesia. Eso sí, con mejor o menor fortuna. La motivación ante aquellos obstáculos, que tratarían de esquivar, son los mismos que tiempo después llegarían a intentar ante la clausura estricta. Y, no fue simplemente, la Iglesia la que trataba de controlar a través de sus superiores jerárquicos, no olvidemos cómo la Corona mantuvo también unos intereses. La Monarquía necesitaba mantener la uniformidad y disciplinamiento social. Mientras las mujeres trataron de encauzar una parte de su poder 
mediante un proceso conocido como Querella de las mujeres ${ }^{1}$, intentado así objetivar y rechazar las dificultades a las que se enfrentaban.

Recordemos, en resumen, cómo los efectos de la religiosidad originada por los beaterios $^{2}$ en la Baja Edad Media formaba parte de los cambios en la mentalidad religiosa del momento, las prácticas devocionales, penitenciales y sacramentales abren puertas a una vivencia religiosa distinta a la seguida hasta entonces. Se trató de una faceta más en la evolución de un proceso que terminaría por alcanzar cotas fundacionales muy amplias en el Siglo de Oro, múltiples vocaciones que comenzaría en 1550 y alcanzará el siglo XVIII. Estos periodos son un momento de gran interés para el investigador, de efervescencia religiosa, de posibilidades, y un cierto nivel de permisividad en la religiosidad femenina cuyo control ofrecía un modelo vocacional muy diferente al que veremos más tarde, cuando insertas en la vida claustral, llegarán a cuestionar nuevamente el enfoque que para ellas está obligado por la clausura estricta.

Deberemos, por tanto, abordar los estudios de la vida religiosa femenina desde otras perspectivas. En primer lugar, considerando al objeto de esas transformaciones la mujer religiosa, que clama por cambiar sus intereses y necesidades de fe, su forma de vida claustral o fuera del cenobio apartada de las necesidades sociales regidas por la Iglesia y la Monarquía. En segundo, analizar los rechazos hacia la institucionalización, primero, y hacia Trento y la clausura estricta después. Será un foco de atención importante al considerar el ambiente socio-religioso, y el cambio de mentalidad de la baja Edad Media hacia el Quinientos. Etapa que anuncia las transformaciones del Barroco y el misticismo. Un proceso largo pero atrayente y fascinante.

Hemos planteado la investigación del presente artículo poniendo el foco de atención en tres objetivos de trabajo dentro de la vida religiosa femenina. Primero, conocer cuáles son los conventos originados en beaterios preexistentes y cómo dieron dicho paso a la institucionalización, qué beaterios quedaron independientes, y en qué grado quedaron como tales de los superiores masculinos. Segundo, cómo afectaron las reformas de recolección y descalcez a las fundaciones creadas en la ciudad castellana. Y, por último, la influencia del Concilio de Trento con las problemáticas que llevaba la aplicación de sus decretos, por las disidencias creadas en numerosas comunidades femeninas. Una faceta de análisis que no se comprendería sin hacer hincapié en los rechazos iniciados en los beaterios.

1 La proliferación de investigaciones y publicaciones sobre la defensa femenina, contamos con un estudio reciente, A. Vargas Martínez, La Querella de las mujeres. Tratados hispánicos en defensa de las mujeres (siglo XV), Madrid, Fundamentos, 2016.

2 La amplitud y variedad de tipologías en torno a los beaterios, emparedadas, beguinas, ermitañas, etcétera, fue ya analizada por G. Cavero Domínguez. Otros autores como María Luisa Bueno Domínguez, José María Miura Andrades, Ángela Atienza, Teresa Vinyoles Vidal, Ángela Muñoz y alguno que iremos señalando. Interesante recordar un artículo de la profesora T. Vinyoles Vidal, "La princesa ermitaña, Eilonor de'Urgell", Anuario de Estudios Medievales, 44/1 (2014), pp. 349-377. Una publicación de la profesora Gregoria Cavero: Inclusa intra parientes. La reclusión voluntaria en la España Medieval, Toulouse, 2010. Y entre lo último que hay publicado, A. Muñoz Fernández publicado en 2017. Numerosas autoras, M. L. Sánchez Hernández, "Las variedades de experiencia religiosa en las monjas de los siglos XVI y XVII", Arenal: Revista de Historia de las Mujeres, 5, 1 (1998), pp. 69-105. Los estudios de, M. L. Sánchez Hernández. Hay otros autores: J. L. Sánchez Lora. La valoración de la mujer entre los religiosos, de J. Sánchez Burrieza, “La percepción jesuítica de la mujer (siglos XVI- XVIII)", Investigaciones Históricas, 25 (2005), pp. 85-116. Para el caso de Toledo, en el último año he presentado un trabajo: L. Canabal Rodríguez, "Beaterio y convento. Origen, evolución y desarrollo de las comunidades regulares de la Orden Franciscana de Toledo", en Congreso Internacional. El Franciscanismo: identidad y poder, Baeza-Priego de Córdoba, 2015, pp. 317-330. Con carácter general me remito a L. Canabal, Los conventos femeninos en Toledo. Siglos XII- XVI, Madrid, Universidad Complutense, 1997, (tesis doctoral inédita). 
Para ello hemos definido un espacio temporal que abarca desde finales del siglo XV y los siglos XVI y XVII, en unos claustros y beaterios localizados en la ciudad de Toledo. Así nos fijaremos tanto en las órdenes mendicantes como en las órdenes monásticas, pero también en una comunidad de freilas de Órdenes Militares. Unos planteamientos que debemos reconsiderar desde las últimas décadas del siglo XV hasta el siglo XVII, último período en que se implantaron comunidades religiosas femeninas en Toledo.

\section{BEATERIOS $Y$ CONVENTOS ORIGINADOS EN TOLEDO. NACE LA AUTOAFIRMACIÓN}

Unir beaterio a convento directamente es ser poco objetivo y generalizar en demasía cuando nos referimos a Toledo. Si bien es cierto que en la ciudad la religiosidad de las mujeres creó una multitud de fundaciones monásticas en el periodo de la reconquista, y que las órdenes militares ayudaron a reorganizar al tiempo que repoblar las áreas toledanas. Los cambios del siglo XIII ubican en la ciudad un floreciente centro urbano muy fértil para el crecimiento de beaterios y cenobios. En gran medida, el crecimiento de las órdenes mendicantes llega a su cenit entre el siglo XV y XVI, con un leve proceso fundacional en el siglo XVII ${ }^{3}$, algunos de los cuales perduraran hasta la actualidad.

La ciudad ${ }^{4}$ incrementó su vínculo con las órdenes mendicantes a través de la implantación de las comunidades de dominicas ${ }^{5}$, agustinas y las distintas opciones femeninas de la orden franciscana ${ }^{6}$, la verdadera propietaria, por así decirlo, de la mayor parte de los conventos toledanos. A lo largo del siglo XV se crearon diez monasterios entre agustinas Beatas Mater Dei o Gaitanas-, clarisas y terciarias -Santa Ana, Santa Isabel de los Reyes, San Antonio de Padua y San Miguel de los Ángeles-, un convento de dominicas, Madre de Dios; la nueva orden de la Inmaculada Concepción y monjas jerónimas -San Pablo y el monasterio de la Encarnación o Vida Pobre-, además de un convento de monjas benitas. El siglo siguiente amplió más el ya de por sí reducido espacio para nuevas implantaciones religiosas, así nacía la fundación de las carmelitas de santa Teresa, monasterio de San José. Poco después, una fundación dominicana: un beaterio, Sancti Spiritus y las agustinas de San Torcuato. Para completar el siglo XVI, la llegada a Toledo de las freilas de Santiago desde Palencia, el monasterio de Santa Fe, fundado a principios del siglo. En el siglo XVII, todavía habrá cabida para la reforma con las capuchinas, el monasterio de la Concepción

3 Para analizar la Iglesia en la Edad Moderna, contamos un número de publicaciones sobre las que cabe destacar para aspectos generales o de carácter historiográfico tres estudios: E. Martínez Ruiz (dir.), El peso de la Iglesia Cuatro siglos de órdenes religiosas en España, Madrid, Actas, 2004; A. L. Cortés Alonso y M. L. López- Guadalupe Muñoz (eds.), La Iglesia española en la Edad Moderna. Balance historiográfico y perspectivas, Homenaje al archivero D. Pedro Rubio Merino, Córdoba, Abada, 2006. Publicación centrada en el clero, Máximo Barrio Gozalo. A. Atienza, Tiempo de conventos. Una historia social de las fundaciones en la España Moderna, Madrid, Marcial Pons, 2008. Diversos aspectos de la vida femenina, el reciente libro J. Burrieza Sánchez (ed.), El alma de las mujeres. Ámbitos de espiritualidad femenina en la modernidad (siglos XVI-XVII), Valladolid, Universidad de Valladolid, 2015.

4 A. Muñoz Fernández, Acciones e intenciones de mujeres en la vida religiosa de los siglos XV y XVI, Madrid, Comunidad de Madrid, 1995. Recordemos también a Blanca Gari de Aguilera.

5 Beaterios y conventos femeninos en Andalucía, los estudios del profesor José Ma Miura Andrades. Véase su estudio "Milagros, beatas y fundaciones de conventos: lo milagroso en las fundaciones dominicas desde inicios del siglo XV a finales del siglo XVI" en La religiosidad popular, Barcelona, Anthropos, 1989, vol. II, pp. 443-460. A. Atienza, "De beaterios a conventos: nuevas perspectivas sobre el mundo de las beatas en la España Moderna", Historia Social, 57 (2007), pp. 145-168.

6 Las ramas femeninas franciscanas son las más numerosas, consúltese: L. Canabal Rodríguez, "La fe de san Francisco y su voz. Continuidad y diversidad fundacional de las ramas femeninas en la Ciudad Imperial (siglos XIII- XVII)", Sémata: Ciencias sociais e humanidades, 26 (2014), pp. 193-219. 
capuchina y las recoletas bernardas de la Asunción unido al último monasterio de las dominicas en Toledo, el monasterio de Jesús y María.

Pero ¿cuántos de ellos tienen su origen en beaterios ${ }^{7}$ y rechazos a la institucionalización? Recordemos un aspecto a tener en cuenta durante una parte del siglo XV. La consideración del Cardenal Francisco Jiménez de Cisneros hacia las beatas del momento. Este factor debe valorarse cuando nos referimos a las comunidades religiosas de la época y al influjo que se aprecia en Toledo. El arzobispo tuvo estima por varias de las religiosas del momento. Como con sor Marta de la Cruz -luego beata terciaria en el monasterio de San Clemente, cenobio sobre el cual nos centraremos más adelante-, incluso llegaría a conocer a la fundadora de las concepcionistas, Beatriz de Silva. Es, por lo tanto, notorio que el propio arzobispo de Toledo tuvo contacto y estimado aprecio por algunas de aquellas mujeres. El cardenal Cisneros $^{8}$ fue una de las piezas clave en la reforma del siglo XIV y XV, su destacado papel en la reforma Observante.

La expansión de beaterios y conventos en Toledo sabemos que fue anterior al siglo XV, en concreto desde el siglo XIII, pero desde entonces abarcamos tres siglos de expansión siendo el siglo XV el más fructífero de los tres. Así, siete de las comunidades nacidas al calor de las reformas de mediados y a finales del siglo XV son implantaciones de beaterios o beatas, agrupaciones posteriormente de terciarias. Verdadera proliferación de beaterios. Así, el monasterio de Santa Isabel de los Reyes lo crea una mujer prototipo de caridad, ayuda a los menesterosos y enfermos, María Suárez de Toledo, hija de los señores de Pinto, que después de enviudar pasa a convertirse en sor María la Pobre, comienza a cuidar de enfermos, residiendo en el Hospital de la Misericordia, terminaría fundando el monasterio de la Orden Tercera de la Penitencia de la Orden de San Francisco en 1483. Pero el origen estaría mucho antes, en 1477, es por ello que esa evolución fue lenta, en parte por la figura de doña María Suárez, con una evolución personal que veremos en otras mujeres de la época.

El paso de una mujer entregada a los demás y beata tercera que asume la necesidad de incluirse en el proyecto de la Iglesia, es uno de los elementos característicos de finales del siglo XV. Esa necesidad de auxiliar a las minorías y más necesitados es uno de los ejemplos frecuentes de las mujeres del momento. El modelo finalmente sería el agruparse en un beaterio, arropadas en los primeros momentos por un espíritu de independencia y rechazo hacia la normativa eclesial. Modelo que cambiará por diversos motivos y que cada comunidad llevó a cabo de forma diversa.

San Miguel de los Ángeles o de los Reyes ${ }^{9}$, otra implantación de la orden franciscana parte de un beaterio. Pasó por los tres estadios, su fundador don Diego López de Toledo,

7 Para su estudio jurídico y social son esenciales los estudios de E. Sastre Santos, "La condición jurídica de beatas y beaterios. Introducción y textos 1139-1917", Anthologica Annua, 43 (1996), pp. 287-586; o, suyo también, La condición de beatas y beaterios, 1997. M. L. Bueno Domínguez, "Santa María de las Dueñas de Zamora: ¿beguinas o monjas? El proceso de 1279", Historia Instituciones Documentos, 20 (1993), pp. 85-105.

8 J. García Oro y M. J. Portela Silva, "La reforma de la vida religiosa en España y Portugal de la vida religiosa durante la Reforma", Archivo Iberoamericano, 62, n. 243 (2002), 455-618; J. García Oro, "Conventualismo y Observancia. La reforma de las órdenes religiosas en los siglos XV y XVI", Historia de la Iglesia en España, vol III, 1, La Historia de la Iglesia de España en los siglos XV y XVI, Madrid, 1980, 210-350. J. García Oro, sus primeras obras sobre el cardenal son de 1971 y 1992. Del mismo autor pueden verse otros libros sobre Cisneros publicados en 2002 y 2005. Otros autores y con la celebración de 2016, la figura del arzobispo de Toledo.

9 L. Canabal Rodríguez, "Fundación y dotación de una comunidad franciscana femenina por un linaje converso. El convento de San Miguel de los Ángeles en el Toledo del siglo XV", Archivo Ibero- Americano, 68, 261 (2008) pp. 529-544. 
casado con María de Santa Cruz, hermano del conde de Cedillo, esto es un miembro del linaje de los Álvarez de Toledo y Zapata, hermano también del secretario de los Reyes Católicos, Fernando Álvarez de Toledo $^{10}$, y del maestreescuela de la catedral primada, don Francisco Álvarez de Toledo ${ }^{11}$. Un linaje converso de gran importancia en la esfera política y religiosa de finales del siglo XV. Don Diego representa el prototipo de benefactor y fundador bajomedieval. Antes de su fallecimiento en 1492, este regidor de Toledo había entregado unas casas a una agrupación de beatas en la collación de San Salvador con anterioridad a valorar la posibilidad de crear un monasterio. Ya durante aquel período las beatas decidieron formar parte de la Orden Tercera de Penitencia regular franciscana, por un documento fechado en 1486. Fallecido en 1492, don Diego en su testamento cede por vía de donación sus casas para que las beatas amplíen la vivienda, pero su esposa imponía una condición destacada, acogerse a la observancia franciscana, además de incorporarse ella misma a la comunidad regular. Estamos ante un interesante proceso en tres pasos en una comunidad iniciada como beaterio independiente antes de la década de los años ochenta del siglo. El patronazgo del linaje converso de los Álvarez de Toledo y la continuidad suponen un rasgo característico de influencia en un simple grupo de beatas que pasaron en dos o tres décadas hacia la uniformidad e inclusión en una orden de vida regular. Pudieron optar por mantenerse como beaterio simple, pero es hasta cierto punto evidente que el linaje benefactor ejerce un cierto nivel de influencia y condicionante en el mantenimiento y desarrollo de esta y otras comunidades femeninas. Es un ejemplo perfecto de esta tipología fundacional que no hemos podido seguir documentalmente en otras fundaciones de la ciudad.

María González es una beata llegada de Ocaña y que terminará por fundar el convento de Santa Ana con fecha desconocida, pero preferentemente se valora la opción de finales del siglo XV, si bien algunos autores la trasladan al siglo XVI, en 1510. Pasaron a terciarias en el momento en que María incrementó el número de beatas que la acompañaban. En cambio, sabemos que residieron en tres viviendas del núcleo urbano, primero en unas casas del duque de Maqueda, en la parroquia de Santo Tomé, enfrente del monasterio franciscano masculino de San Juan de los Reyes, influencia directa suponemos recibieron de esta comunidad tan cercana. Luego pasarían a unas casas muy próximas a la iglesia de Santa María la Blanca en 1513. Pero terminarían en unas viviendas compradas en 1527 denominadas de la "ricafembra". Muy escasos son los datos de esta comunidad.

Antes de 1484 localizamos otra comunidad de beatas en la parroquia de San Román, nos referimos a dos hermanas, María González de la Fuente y Catalina de la Fuente, de origen converso, una familia de mercaderes. Ellas lograron fundar el convento de San Antonio de Padua, de terciarias franciscanas originado en otro beaterio. Las beatas recibieron unas casas según testamento de María González. Su hermana Catalina se convierte en la encargada de hacer cumplir su testamento como albacea, y en 1513, el 15 de diciembre, se firmaba una petición por parte de las beatas para formar parte de la orden tercera de la penitencia en la orden franciscana, lográndolo al año siguiente en 1514 con el apoyo y la firma el 25 de mayo del cardenal Cisneros. La petición de esta solicitud

$10 \mathrm{M}^{\mathrm{a}} \mathrm{C}$. Vaquero Serrano se ha interesado por esta figura del secretario real.

11 La figura y personalidad del maestrescuela ha sido relegada. Relación con el convento de San Miguel de los Ángeles, L. Canabal Rodríguez, "Conversos toledanos en un espacio de poder, la Catedral Primada. Don Francisco Álvarez de Toledo, canónigo y mecenas (siglos XV-XVI)", Espacio, Tiempo y Forma, Serie IV, Historia Moderna, 24 (2011), pp. 13-32. Véase: L. Canabal Rodríguez, "Don Francisco Álvarez de Toledo, maestrescuela de la catedral y benefactor del convento de San Miguel de los Ángeles de Toledo", Archivo Ibero-Americano, 66 (2006) pp. 269-290. "Relación entre dos instituciones de Toledo: el Colegio de santa Catalina y el convento de San Miguel de los Ángeles", Anales Toledanos, 43 (2007) pp. 47-71. 
por parte de las beatas es un testimonio conservado poco habitual, y ofrece una visión de gran valor para comprender la fuerte presión por la cual pasaban las beatas entre finales del siglo XV y el XVI para incorporarse a una orden religiosa, aunque fuera a una orden tercera. Es complicado fijar una continuidad en cuanto a la denominación y la división entre beatas y monjas terciarias o beatas terciarias, ya que la documentación llega a confundir la denominación e incluso se admiten las dos denominaciones, sin lograr tener claro la división estricta.

Los orígenes de las jerónimas, por otra parte, no se aleja mucho de las comunidades que hemos observado hasta aquí. El primer monasterio femenino de la Orden en la península es el monasterio de San Pablo. No obstante, no será hasta 1408 con la profesión de las ya monjas, fueron primero un grupo de beatas. El beaterio de San Pablo nace de la iniciativa de otra mujer del linaje toledano de los García de Toledo. Doña María García de Toledo es otro de los ejemplos de mujer que pasa por varias etapas en su juventud para terminar formando un beaterio. Su evolución personal es bastante parecida a la que hemos visto antes, la fundadora del convento de Santa Isabel de los Reyes, sor María la Pobre, para el mundo María Suárez de Toledo. Ambas son mujeres de linaje destacado en Toledo, coinciden casi temporalmente y María García pasó una larga temporada en el monasterio de San Pedro de las Dueñas, de monjas benedictinas, donde estaba su hermana, la abadesa doña Teresa. Retirada luego a la ermita de Santa María de la Sisla, el contacto con el fundador del monasterio masculino de la orden en la Sisla, Pedro Fernández de Pecha o fray Pedro de Guadalajara, figura esencial de la orden, con quien establece amistad y un grado de influencia que la llevará a la creación del beaterio. Sin embargo el proceso fue lento pues María García hasta llegar a la vida de beata, residió en una casa de beatas muy desconocida, la casa de María de Soria. Desde allí y junto a una presencia trascendental para ella, su gran apoyo, otra mujer Mayor Gómez. Entre ambas nacía el beaterio. Esta agrupación no llegará a incluirse en la orden jerónima hasta 1464. Si bien hasta 1510 no formaría parte de la orden de manera jurídica.

Otra de las comunidades de monjas jerónimas nacida en el siglo XV, en 1493, es de nuevo un monasterio cuyo origen está en un beaterio, el conocido como de doña María Díaz de Segovia. Luego monasterio de la Encarnación o Vida Pobre.

No lejos de las fundaciones señaladas brota otra casa de beatas gracias al apoyo de otra mujer toledana, doña Guiomar de Meneses, esposa de Lope Gaitán, portero mayor del rey en Toledo. El matrimonio había donado una parte de unas casas para el conocido Hospital de la Misericordia. Doña Guiomar decidió entregar unas casas para residencia de seis beatas que vivían próximas y quienes finalmente se trasladaron allí a la parroquia de Santa Leocadia. Serían conocidas como las Gaitanas ${ }^{12}$ en 1459. Pero lo más llamativo de la donación de doña Guiomar es el hecho de no obligar a las beatas a tomar ninguna regla aprobada. Esto las mantenía alejadas de una orden y fuera de la órbita de una jerarquía masculina, hecho poco habitual entonces. Si bien a lo largo del siglo XVI se producen cambios en el beaterio que terminan por ser incorporadas en la Orden de San Agustín, en 1627. El ideal de beaterio independiente pensado por doña Guiomar fue alterado por completo.

La única comunidad de monjas dominicas que fue fundada en el siglo XV fue el monasterio de Madre de Dios. Es el segundo creado en Toledo después de Santo Domingo el Real ${ }^{13}$. La originalidad de esta comunidad no está solo en su nacimiento bajo el proceso

12 Sobre las agustinas de Toledo, L. Canabal Rodríguez, "Las religiosas agustinas en Toledo. Medios de adquisición patrimonial, (s. XIV-XVII)", Archivo Agustiniano, 83, n. 201 (1999), pp. 137-159.

13 Sobre la Orden de Predicadores en Toledo, E. Serrano Rodríguez, Toledo y los dominicos en la época medieval. Instituciones, economía y sociedad, Madrid, Síntesis, 2016. 
de reformas del siglo XV, que ya de por sí es muy importante para la Orden de Predicadores. Es, a su vez, para lo que aquí analizamos, su origen en la unión con un beaterio preexistente. El convento y el beaterio llegaron a formar una única unidad a finales del siglo XV. No se trata de los casos anteriores cuando el origen del convento parte de un beaterio, pero es un ejemplo de gran valor para comprender mejor la pluralidad en torno a las fundaciones toledanas y sus peculiaridades. Interesa destacar otro aspecto a valorar, el monasterio de las dominicas nacía envuelto en la reforma de la observancia dentro de la Orden y debemos hacer hincapié en ello, pues como hemos comprobado solamente en dos conventos creados en esta etapa de finales del siglo XV se involucran de manera decidida en ese instante para su fundación, este del que ahora hablamos y el de las concepcionistas de la Inmaculada. Doña María Gómez de Silva, el linaje al que pertenece doña María, los Silva, hija del II conde de Cifuentes, es uno de los más importantes de la ciudad y la relación de su familia con la Orden de Predicadores viene de lejos, sus abuelos paternos fueron los fundadores del monasterio masculino de San Pedro Mártir. Doña María comienza comprando unas casas en la parroquia de San Román para cobijar un beaterio, este acontecimiento fechado en 1483, apenas tres años después de la fundación del masculino de San Pedro Mártir. La agrupación de beatas incluidas en la Orden Tercera de Penitencia. Vivieron de manera independiente hasta la aparición en escena de otro beaterio anterior al creado por sor María Gómez. Nos referimos al beaterio de santa Catalina de Siena existente desde 1424 de la orden tercera. Próximos, ambos beaterios, al monasterio masculino de San Pedro Mártir, es ciertamente ineludible pensar que la influencia de la Orden de Predicadores ${ }^{14}$ quedó definitivamente inserta en los intereses de incorporar ambos en uno y así originar un único convento femenino de la orden dominicana, en plena etapa de observancia.

Lo que en principio parece una unión de dos beaterios es bastante posterior, pues esta se lleva a cabo en 1491. Y fue más de una década antes en 1483, cuando doña María hacía una petición para formar un convento al arzobispo de Toledo, don Pedro González de Mendoza. El momento decisivo llega con la concesión de la bula en 1486, el 27 de junio, el papa Inocencio VIII (1484-1492) otorgaba a sor María Gómez el beneplácito del permiso fundacional. La reforma de la observancia dentro de la Orden de Predicadores en Toledo simboliza en la década de los años ochenta del siglo el momento adecuado para incorporar una comunidad femenina entonces beaterio, que en la siguiente década añade otro beaterio de terceras. Este hecho es único, al crear un convento partiendo de dos beaterios de terceras. Solamente hay otro ejemplo similar en la ciudad, otro monasterio de monjas agustinas que estudiaremos después ocurrido en el siglo XVI, San Torcuato.

De todas las implantaciones conventuales que hemos señalado cabe para terminar este apartado centrarnos en dos comunidades, las concepcionistas y un monasterio de monjas benitas, beatas en su origen. Así, en 1484 don Diego Fernández de Úbeda, bachiller y cura de la capilla de San Pedro de la catedral donaba unas casas para beaterio. La agrupación llegará a tomar clausura con la regla de San Benito de Nursia en 1629 y la institucionalización tardará en producirse, con la reforma de las recoletas en 1652. Sobre ambos volveremos más adelante, con la activación de los procesos de reformas.

El manto de incertidumbre que supone la creación de un convento para su fundador o para cualquier agrupación de beatas dependientes del auxilio de un buen benefactor, refleja una evolución, en muchas ocasiones, compleja y diversa. Si nos centramos en el convento de la Inmaculada Concepción, el punto de partida de la Orden de la Inmaculada Concepción nacida en Toledo, estamos ante otra personalidad femenina reconocida por

14 E. Serrano, "Piedad, nobleza y reforma. La fundación del monasterio de la Madre de Dios en Toledo (1483)", Archivo Dominicano: Anuario, 33 (2012), pp. 213-237. 
sus contemporáneos incluso por la propia reina Isabel. Doña Beatriz de Silva y Meneses representa otra faceta de las vivencias de la religiosidad bajomedieval. Esta mujer de origen portugués es la fundadora del convento, y posteriormente nueva orden inserta en la orden franciscana. Una nueva orden ${ }^{15}$, una nueva opción de vida religiosa para las mujeres. La implantación de la Orden está inserta en las reformas cisnerianas, pero merece una mención especial en el siguiente apartado.

La proliferación en el Toledo del siglo XV de los beaterios, en concreto nueve, originarios de los subsiguientes conventos, nos permiten comprender mejor la importancia de estas agrupaciones femeninas que, frente a las acciones coactivas y las diversas acciones normativas de las futuras comunidades de vida regular, han iniciado su vida comunitaria fuera de las obligaciones uniformes de la Iglesia. Concluyeron como conventos pero en sus orígenes, por muchos motivos, las beatas estuvieron fuera de la institucionalización.

\section{CÓMO AFECTARON LAS REFORMAS A LAS NUEVAS FUNDACIONES: RECOLECCIÓN, DESCALCEZ, CONCEPCIONISTAS Y CAPUCHINAS. SIGLOS XVI Y XVII}

La aparente incapacidad para implantar la clausura estricta no minusvalora el resto de procesos de reformas activados desde el siglo $\mathrm{XV}^{16}$. Aquella etapa de reformas anuncia una etapa amplia de cambios para la vida regular, en especial para las monjas, y los pocos beaterios existentes. ¿Y cómo separar las nuevas fundaciones de las reformas? Es indudable que con el siglo XVI y XVII no sólo el Concilio de Trento y los concilios provinciales serán una parte de todo el entramado reformista -donde se mantiene una estrecha relación entre los intereses religiosos- enfocado hacia las reformas y otra parte fundamental, los intereses de la Corona -la política-, y una defensa de la ortodoxia en todos los ámbitos, así como una búsqueda de los medios más eficientes para logarlo. Para ello se proponen implementar la reforma. Para el control de la ortodoxia, una de las vías fue la creación del Santo Oficio y la implantación de los estatutos de limpieza de sangre. Tiempo después, el concilio de Trento reorganizaría muchos aspectos que habían quedado relegados.

La inquebrantable fidelidad a la ortodoxia y mediante ella a la Corona y la Iglesia, estuvo muy controlada en la vida regular femenina. Si durante la Baja Edad Media habían ido creándose las órdenes mendicantes en el creciente impulso urbano, el Renacimiento abría las puertas a nuevas órdenes más acordes con las nuevas vivencias religiosas, se trata de los jesuitas y los capuchinos que entraban en el esquema de la ortodoxia católica. No obstante, hay un lapso de tiempo durante el inicio del reinado del emperador, en que la ciudad de Toledo cobija una desafección al influjo y poder real, que numerosos frailes y también monjes defienden con ferviente ardor. Para muchos contemporáneos aquellos sermones, algunos desde el púlpito de la catedral, y panfletos recogen una fuerte desafección que culmina con la ciudad al frente de la revuelta de las Comunidades.

15 Citemos a R. Conde, Vida de la Beata Beatriz de Silva. Fundadora de la Orden de la Purísima Concepción, Madrid, Editorial Ibérica, 1931; J. Omaechavarria y Enrique Gutiérrez. De este último, E. Gutiérrez, Beata Beatriz de Silva y origen de la Orden de la Purísima Concepción, Valladolid, Server Cuesta, 1967. M. M Graña Cid, Beatriz de Silva (ca. 1426-ca 1491), Madrid, Ediciones del Orto, 2004. Biógrafo de doña Beatriz, J. F. Duque Fernández da Silva, Doña Beatriz de Silva. Vida e obra de una mulher forte, Labryrinthus, Maia, 2008. Publicada en español. Además, J. Meseguer.

16 En el siglo XV, las reformas dieron lugar a resistencias femeninas en cualquier orden. Los datos son escasos, pero poco a poco van apareciendo. Así los acaecidos en el Monasterio de Montesión, de dominicas, de Barcelona. M. S. Hernández Cabrera, "La celda del convento, una habitación propia. La vivencia de la clausura en la comunidad de dominicas de Montesión", Duoda: Revista de Estudios Feministas, 22 (2002), pp. 19-40. 
Pero eso es un tema en el cual las mujeres de vida claustral ${ }^{17}$ y los beaterios de entonces, miran desde un espacio de vivencia regular con cierto alejamiento. En Toledo nacen nuevos conventos, o llegan otros derivados de traslados motivados por la reorganización territorial como fue el caso de las freilas ${ }^{18}$ de la Orden Militar de Santiago. Incluso, la reforma descalza, la recolección, o tiempo después, las capuchinas contribuyen a propiciar importantes cambios.

La preeminencia de las órdenes mendicantes en Toledo esboza fielmente el efecto que sus comunidades femeninas, siempre más numerosas, tuvieron en su núcleo urbano. La reforma interna llevada a cabo por Cisneros en base a beneficiar a los partidarios de la observancia, tiene otro punto muy importante en la reforma de los cenobios. De toda esa evolución cabe destacar el nacimiento de dos conventos, los dos de orden mendicante, el convento de las carmelitas descalzas del convento de San José -creación de la propia Santa Teresa de Jesús- y el convento de las monjas concepcionistas, la nueva orden que nace en el siglo XV, pero tiene su máximo desarrollo institucional en el siglo XVI.

Las nuevas voces nacidas en el siglo XV buscaban y pedían una nueva reforma de las órdenes y salir de la decadencia en que habían caído. Y como ya señalamos entre estas reformas originadas entre el siglo XV y el XVI estaba el convento de la Inmaculada Concepción ${ }^{19}$ al cual nos referimos antes, pero que merece una más amplia exposición, al tratarse de una interesante comunidad origen de una nueva orden femenina, cuya regla y constituciones ${ }^{20}$ propias fueron redactadas en la primera década del siglo XVI. Reseñemos una etapa anterior, el rechazo a la unión de dos comunidades que costaría asumir por parte ambas partes, y principalmente, de las herederas de la fundadora de las concepcionistas, doña Beatriz de Silva. Aquel proceso de unión fue promovido y ejecutado a finales del siglo XV, hacía 1492. Las monjas, ahora bajo la regla de Santa Clara, se fusionaron con el monasterio de San Pedro de las Dueñas, de monjas benedictinas. El motivo de este hecho hay que buscarlo en la carencia de patrimonio de la comunidad creada por doña Beatriz además de las infracciones llevadas a cabo por las monjas de San Pedro de las Dueñas. Un monasterio creado durante la expansión monástica del siglo XII en el núcleo urbano de Toledo daba un giro de ciento ochenta grados para fusionarse con una comunidad nueva del siglo XV. Para ello la reina pidió al papa Alejandro VI la licencia debida y llegaría la bula

17 Para la vida comunitaria, L. de Ahumada, "Biografías femeninas. Historias de vida dentro de las comunidades religiosas (siglo XVII)", Itinerantes. Revista de historia y Religión, 1 (2011), pp. 41-55. Incluso su papel en la sociedad, véase la autora, F. Morand.

18 Sobre esta comunidad de freilas santiaguistas llegadas desde Santa Eufemia de Cozuelos de Palencia preparamos un estudio.

19 En torno al dogma y en defensa de su proclamación, J. A. Peinado Guzmán, "La monarquía española y el dogma de la Inmaculada Concepción: fervor, diplomacia y gestiones a favor de su proclamación en la Edad Moderna", Chronica Nova: Revista de la Universidad de Granada, 40 (2014), pp. 247-276.

20 Las Constituciones estudiadas por J. Meseguer Fernández, "Primeras constituciones de las franciscanas concepcionistas", Archivo Ibero-americano, 25, n. 100 (1965), pp. 361-389. L. Canabal Rodríguez "Constituciones de una comunidad concepcionista. El monasterio de la Concepción de Toledo", en I Congreso Internacional del Monacato femenino en España, Portugal y América (1492-1992), León, Universidad de León, 1993, vol. 3, pp. 203-211. Para la fundadora, doña Beatriz de Silva, con posterioridad santa Beatriz, E. Gutiérrez, Beata Beatriz de Silva y origen de la Orden de la Purísima Concepción, Valladolid, Server Cuesta, 1967. Más reciente, J. Eduardo Franco, J. Sánchez Alvés (coords.), Santa Beatriz da Silva. Uma estrela para novos rumbos, Cascais, Principia, 2013. L. Canabal Rodríguez, "Dos reinados y dos cortes. Una dama portuguesa en la corte castellana. Doña Beatriz de Silva y Meneses (1447-1491)", en Reinas e infantas en los reinos medievales ibéricos. Contribuciones para su estudio, Santiago, Universidad de Santiago, 2015, pp. 361-385. Procesos de unión o cambio de orden N. Jornet Benito, "Santa Clara de Barcelona, 1513: de clarisas a benedictinas, un paso a esclarecer”, Itinerantes. Revista de Historia y Religión, 2 (2012), pp. $173-188$. 
Apostolicae sedis el 1 de septiembre. El día 5 de noviembre se realizaba la unión con el consentimiento de las monjas de Santa Fe, las futuras concepcionistas. La pretendida unión trajo consigo alteraciones y rechazos. La determinación de la heredera de doña Beatriz, su sobrina Felipa de Silva, por mantener las ideas de independencia de las mujeres que habían creado la comunidad y su futuro, con un sostenimiento del ordinario que no agradaba a la reina Isabel influida muy probablemente por su confesor, don Francisco Jiménez de Cisneros, es el segundo paso de las reformas. Es más, la preocupación por las dificultades de reformar a los monasterios bajo la regla de San Benito con sus fundaciones sujetas al ordinario tuvo mucho que ver en este paso. Las monjas de San Pedro de las Dueñas no veían con buenos ojos, como su patrimonio mucho más importante, que el apenas inexistente de las monjas de Santa Fe, se viera incluido entre ambas comunidades y, por tanto, repartidos sus beneficios. Al mismo tiempo, tampoco fue de su agrado la pérdida de cierto grado de libertad de las monjas de San Pedro que había desaparecido, unido a la pérdida de su hábito y tomar la regla de Santa Clara para pasar a depender de los frailes franciscanos era para ellas inaceptable. Sus pretensiones y rechazos se centraron en quitarle el gobierno a la nueva abadesa, doña Felipa, alegando que habían sido engañadas en este proceso de unión y reformas hacía la observancia. Y no fueron solo aquellas las desafectas al proceso de unión, una parte de las monjas de Santa Fe, a cuyo frente estaba doña Felipa de Silva, rechazaron de manera inmediata la unión con las benedictinas. Su forma de oposición fue la de salir del convento y llevarse consigo los restos de la fundadora que había fallecido antes de esta problemática unión, en $1492^{21}$. Salió con un grupo de adeptas en al menos en varias ocasiones salía y regresaba al convento, incluso en el año 1500 estaba fuera del monasterio, para finalmente no volver quedando con algunas de sus compañeras en el monasterio dominicano de Madre de Dios.

Es necesario hacer hincapié en que no se trata simplemente de un rechazo a la unión con las monjas benedictinas en ese proceso reformista de observancia, se trata asimismo de una cuestión de seguir la línea de independencia que la abadesa doña Felipa observaba se alejaba de las intenciones primigenias de su tía doña Beatriz. Ese alejamiento, que trataba de forzar a doña Felipa, se logró, pues los frailes del monasterio de San Francisco fueron trasladados por la reina y quedó el monasterio para las dos comunidades femeninas unidas ya en el monasterio de Santa Fe de la Concepción. Todo ello entre 1501 y 1506. Históricamente, se atribuye aquella ampliación conventual y patrimonial a una motivación de espacio al haberse incrementado el número de monjas. Pero había mucho más detrás de dicho proceso.

La trascendencia de la comunidad de Santa Fe está precisamente en el cambio producido cuando las monjas logran que se reconozca su especificidad, y ello posibilite la redacción de una Orden propia y unas constituciones inherentes a su estatus como monjas concepcionistas, entre 1507 y 1515. La salida de doña Felipa supuso una nueva elección de abadesa del monasterio de Santa Fe, doña Juana de San Miguel, que pasó a ser vicaria, y doña Catalina Calderón, antigua monja benedictina de San Pedro de las Dueñas, que pasaba a convertirse en abadesa. Ellas, hacia 1506 abadesa y vicaria, solicitan al papa la ratificación del traslado, ya definitivo, de la comunidad al monasterio de San Francisco, pero además hacían otras peticiones.

Y todo lo aprobó de su Santidad y lo confirmo, supliendo cualquier defecto si acaso le hubo, y mandó que dejando los títulos que tenían las tres casas, Santa Fe, San Pedro de las Dueñas y San Francisco, solo retuvieren el título de la Concepçión, forma de hábito dicho y

21 Archivo del Monasterio de las Concepcionistas de Toledo, (A.M.C.T), libro de registro, fol. 112 r. 
la regla de Santa Clara y, las dos casas de Palacios de Galiana, Santa Fe y la casa de San Pedro, lo aplica por hacienda propia ${ }^{22}$.

Todo ello, confirmado por el papa Julio II en la bula Pastorali Oficii el 19 de febrero de $1506^{23}$. El verdadero avance, por otra parte decisivo, fue la bula de Julio II "Ad statum prosperum" confirmada el 15 de octubre de 1511. La regla, con 12 capítulos, además de confirmar el hábito y modo de oficio divino. Todo el proceso finalizaba el 4 de noviembre de 1512.

Así pues, de los rechazos iniciales a la unión de las dos comunidades y la intromisión de los franciscanos por parte de una facción de las monjas, ¿podría considerarse un primer rechazo o la negación a la unión con las monjas de San Pedro de las Dueñas? Estimo que sí lo fue, pero no el único ${ }^{24}$. De cualquier forma, el enfrentamiento finalizaría con la obtención de una orden propia, pero finalizaría con un voto de clausura. Necesitamos saber si en los primeros años fue motivo de oposición.

Merece la pena detenerse un poco más en las reformas de los siglos XVI y XVII25. Así, entre el siglo XVI y XVII, la orden de Santo Domingo implantaba un convento en el siglo XVII y un beaterio un siglo antes en Toledo. El beaterio al que nos referimos es un original modelo del único beaterio toledano que subsistió y es conocido. El beaterio de Sancti Spiritus no evoluciona hacia un convento formal. Es un caso de gran valor dentro del marco toledano y castellano. Afamado en la ciudad, este beaterio fue un beaterio de orden tercera dependiendo de la Orden de Predicadores. Sin embargo, la vivencia de este beaterio se aleja de lo habitual en torno a estos beaterios terceros que fueron absorbidos para institucionalizarlos y hacerlos llegar a convertirlos en conventos con votos estrictos. El reducido número de sus beatas, sumado a un exiguo patrimonio le lleva a terminar su andadura en un siglo.

La iniciativa e idea del proyecto nace de Martín Alfonso de Hinojosa ${ }^{26}$, maestresala del II conde Cifuentes, Alonso de Silva, y su esposa Francisca Suárez. He ahí la relación con la Orden de Predicadores, la relación con el linaje Silva. Para conocer sus primeros pasos, la fuente con la que contamos son los testamentos de este matrimonio de fundadores. Martín Alfonso de Hinojosa firmaba su testamento el 10 de febrero de 1505, en él hacía donación de todos sus bienes, no muy amplios, a la Orden de Predicadores.

Este proyecto, como vemos, quedaba de forma muy próxima a la Orden de Predicadores, pero su nivel de independencia era algo complicado, pues su ligazón a la orden dominicana deja entrever unos muy limitados elementos de libertad, la trasgresión y la limitada autonomía podrían afectar solo al hecho de mantener la denominación de beaterio.

22 A.M.C.T, libro registro, fol. $113 \mathrm{r}$.

23 Ibídem, fol. $114 \mathrm{v}$.

24 Rechazos en la orden de las concepcionistas, L. Canabal Rodríguez "La reforma franciscana entre las monjas del siglo XV. La nueva orden de la Inmaculada Concepción", en Congreso Internacional. El Franciscanismo: identidad y poder, Baeza y Priego de Córdoba, 2015, pp. 395-420.

$25 \mathrm{~N}$. Terpastra, Religious refugees in the Early Modern World, an alternative history of the Reformation, Cambridge, Cambirdge University Press, 2015.

26 E. Serrano, "El patrocinio nobiliario de la vida en común: el beaterio dominicano del Espíritu Santo de Toledo", Territorio, sociedad y poder: revista de estudios medievales, 4 (2009), pp. 227-237. Y aportaciones en L. Canabal, Los conventos..., Ibídem. Sobre el convento de Jesús y María: P. Penas Serrano, El convento de Jesús y María de Toledo, Toledo, Bremen, 2000; B. Martínez Caviró, "Juana de Castilla fundadora del monasterio de Jesús y María”, Beresit, Toledo, II (1998), pp. 23-36. Lo último, L. Canabal Rodríguez "Clausura en el siglo XVII: el convento dominicano de Jesús y María en Toledo", Toletana. Cuestiones de Teología e Historia, 14 (2006) pp. 137-160. 
El convento de Jesús y María fue una creación de una mujer de linaje, doña Juana de Castilla y Toledo, descendiente por línea paterna del rey Pedro I, por su hijo Diego de Castilla. Doña Juana, viuda de don Fernando Niño, el segundo señor de los Tejares, ocurrida en 1562. La herencia de su marido firmaba su testamento el 6 de julio de 1560, convirtiéndola en heredera de todo su patrimonio, salvó la mitad de los bienes que formaban el mayorazgo, en cuyo caso se convertía en usufructuaria.

No fue fácil para ella decidirse por una orden en el instante de decisión fundacional. Estamos ante un caso bastante peculiar, durante más de casi cuarenta años, entre 1568 hasta 1599 , los problemas derivados de las viviendas para el convento por producirse un largo pleito con el I marqués de Malpica, Pedro de Ribera; $y$, en segundo lugar porque solucionada esta interferencia, doña Juana, deseosa de incorporar su fundación en los procesos de reformas encauzados entre finales del siglo XVI y comienzos del siglo XVII, no se decidía entre las carmelitas descalzas, deslumbrada por la reciente llegada de santa Teresa a Toledo para fundar. Luego, pensó en la orden franciscana descalza o agustiniana recoletas. Finalmente, elige la orden de Predicadores, en la descalcez. En aquella comunidad incluyó la posibilidad de permitir la entrada a varias mujeres que no aportaran dote, limitando su número a cinco. La primera licencia recibida por doña Juana fue la del arzobispo de Toledo don Gaspar de Quiroga y Vela (1577-1594) el 24 de mayo de 1593. En 1595, doña Juana volvía a solicitar una licencia fundacional al deán y cabildo de la catedral para ahora elegir la Orden de san Agustín o de san Francisco. Finalmente, el 19 de enero de 1599 recibe doña Juana la licencia para fundar en la descalcez un monasterio de dominicas. El 23 de agosto de 1619 está fechado el testamento de doña Juana, su deceso ocurría cuatro días más tarde. El documento aporta en varias mandas importantes datos sobre el futuro del monasterio: elección de patronos, de capellanías. Todos elementos clave de la tipología fundacional de los monasterios contrarreformistas, en el cual se inserta esta comunidad. Al mismo tiempo, en su testamento menciona su intención de que la Orden de Predicadores fundara a las afueras de Toledo un monasterio de dominicos recoletos. Hecho que no llegó a realizarse.

En el periodo analizado, hay que advertir la presencia de la última comunidad de monjas agustinas fundada en la ciudad. A principios del siglo XVI se sitúa el establecimiento de un beaterio ${ }^{27}$ denominado de Santa Mónica en 1520, además nos consta que otro beaterio, el de las Melgarejas de finales del siglo XV, ambos terminarían por unirse en el futuro convento de San Torcuato. El beaterio de las Melgarejas, que vivían con el hábito de San Agustín. Dos beaterios, un convento de la orden agustiniana después que a finales del siglo XVI, en 1592, el arzobispo don Gaspar de Quiroga y Vela, las diera velo y clausura. De nuevo el proceso de reformas observantes absorbe dos beaterios.

¿Qué ocurría con la rama femenina de los franciscanos? El monasterio de San Juan de la Penitencia, que bien indica su adscripción a la rama tercera, representa un modelo de convento- colegio en imitación a otra fundación llevada a cabo por el mismo cardenal Cisneros en Alcalá de Henares con el cual compartía las constituciones El monasterio toledano lo fundaba el cardenal en 1515 con una doble utilidad social para del siglo $\mathrm{XVI}^{28}$.

27 M. L. Giordano, "Entre experiencia subjetiva y creación de un modelo: el caso de dos beatas en España entre los siglos XVI y XVII", en De los símbolos al orden simbólico femenino:( siglos IV-XVII), Madrid, Almudayna, 1998, pp. 317-334.

28 La educación de la mujer estará centrada años después de la creación cisneriana del monasterio-escuela de San Juan de la Penitencia. L. Canabal Rodríguez, "Mujer y reclusión en el siglo XVI. Fundación y estatutos de la Casa de Nuestra Señora del Refugio en Toledo", Tempus. Revista en Historia General, 2 (2015), pp. 1-38. 
Un primer paso que seguirá a finales mediados del siglo, en 1551, el arzobispo toledano don Juan Martínez Silíceo, con el Colegio de Doncellas Nobles ${ }^{29}$ en Toledo, terminaría por pasar al patronato real en 1560.

El carácter educativo de la creación cisneriana ejemplifica el proceso de cambio vivido por la sociedad al inicio del Quinientos. El colegio formaba a jóvenes doncellas en la regla franciscana, una labor que llevaban a cabo la superiora del convento y las monjas. Las primeras monjas Ilegaron del monasterio de Almagro, Nuestra Señora de los Llanos, un centro en el que Cisneros estuvo en el oficio de guardián en 1493. Las Constituciones de los dos centros, si bien eran compartidas, con el creado por Cisneros en la misma época en Alcalá de Henares, en el toledano, con el discurrir del tiempo, debieron ser revisadas, y fueron además, más que una simple revisión. El secretario del cardenal, don Francisco Ruiz, obispo de Ávila, se encargó de redactar unas nuevas constituciones para los dos centros. Las constituciones del convento y del colegio de doncellas. Sobre las del convento, los esquemas centrales son bien concretos, la pobreza, la dignidad de la obediencia, la oración, el trabajo, el cuidado puesto en la práctica de la caridad, la penitencia. El contenido está distribuido en diez capítulos. Para el colegio de doncellas ordenaba el obispo de Ávila un reglamento en seis capítulos ${ }^{30}$. Las doncellas recuperaban el apoyo económico para casarse o para entrar en el convento, este u otro de la ciudad, por medio de la dote en uno u otro caso.

La contribución de las monjas franciscanas ofrecía una nueva comunidad, con una posibilidad educativa novedosa para la época. Los posibles rechazos en esta comunidad o a otras posteriores a lo largo del siglo XVII no serán muy evidentes documentalmente, en buena medida porque en el Seiscientos las comunidades implantadas provenían de las nuevas ramas de la reforma y contrarreforma, capuchinas o recoletas.

Los ritmos de implantación conventual entre el Quinientos y Seiscientos forman un significativo refuerzo de la reforma de la descalcez, recolección. Desde el principio, se advirtieron en Toledo elementos de adaptación y aceptación de aquellos procesos de reforma como ya había ocurrido en las reformas del siglo XV. Existe un dato significativo desde 1568 y $1630^{31}$, nacen los tres monasterios femeninos aportación particular de la ciudad al largo proceso de la Modernidad, al tiempo que se traduce el valor que alcanzaran las capuchinas toledanas. La riqueza vocacional del momento iniciada en la segunda mitad del Quinientos, se constata en el censo de 1591, aunque solo sea para la Corona de Castilla. Las casas donadas para las fundaciones, con un patrimonio más limitado del que hasta entonces las comunidades habían gozado. Tampoco terminará por frenar la concesión de licencias ni el fervor fundacional, ni tan solo el apoyo real. Las casas masculinas y la llegada de los jesuitas influirá sobre manera en la ciudad, pero eso es otro tema.

Esta situación de apego directo a la fundación y formación de conventos de monjas reformadas se aleja de la anterior etapa de creación conventual, originadas en gran parte

29 Este centro específico para la formación femenina de nobles se convertiría en el segundo para a la mujer en la ciudad. De la autora, unas Constituciones inéditas, "Educación femenina en la Edad Moderna: constituciones del Colegio de Doncellas Nobles de Nuestra Señora de los Remedios, Toledo (siglo XVI)", Estudios Humanísticos. Historia, 12 (2013), pp. 127-154.

$30 \mathrm{El}$ análisis de estas constituciones lo ha realizado en dos artículos, el padre A. Abad Pérez.

31 La década de los treinta es una etapa floreciente en fundaciones reformistas en toda Castilla, y todavía hay beaterios. A. Ceballos Guerrero, "Ellas y ellos. Un análisis de la fundación del convento de Santo Tomás de Villanueva de Granada en clave de género", Chronica Nova, 41 (2015), pp. 145-168. El estudio se centra en un beaterio en el Albaicín en 1636, que da lugar a dos conventos de recoletas. Los estudios sobre los recoletos agustinos el experto en Mariana de San José, J. Díez Rastrilla, Mariana de San José. Fundación del monasterio de Valladolid (1606-1610), Madrid, BAC, 2015. 
en beaterios. El cambio de siglo y la actividad producida por el Concilio de Trento permite una gran representación activa de las monjas descalzas, con las carmelitas de santa Teresa y las franciscanas capuchinas de la Concepción Capuchina. En el otro lado de la reforma vivida en Toledo se instalan las recoletas bernardas de la Asunción y la transformación de las antiguas beatas de don Diego Fernández de Úbeda, en el siglo XVII ${ }^{32}$, convertidas en recoletas benitas.

Las carmelitas descalzas de Santa Teresa ${ }^{33}$ Ilegaban a Toledo en 1562, pero no será hasta 1568 cuando llega la propuesta para fundar en la ciudad. En los años iniciales del siglo XVII y antes del declive fundacional vivido hacia 1650 nacen las restantes comunidades femeninas. Las fundaciones contrarreformistas son esenciales, pero debido a las limitaciones de espacio en el presente artículo daremos unas breves pinceladas.

La aparición de la comunidad de recoletas bernardas es fruto de la intención fundacional del licenciado don Fernán Pérez de la Fuente, con la advocación a Nuestra Señora de la Asunción en 1604. El testamento de su fundador presenta unos objetivos concretos que don Fernán había fijado y diseñado con todo detalle, su número doce monjas y entre ellos el derecho de presentación de las monjas, incluida la elección de abadesa en un miembro de su linaje. Su tipología refleja fielmente el espíritu de la Contrarreforma.

Las franciscanas capuchinas llegan con las reformas por deseo fundacional de doña Petronila Yánez ${ }^{34}$, viuda de don Pedro Lasso Coello, quien redacta una petición en 1631 para la creación conventual de la reforma franciscana de los capuchinos. Para conocer el último efecto de las reformas de vida regular en la ciudad es necesario retrotraerse al siglo XV. Volvamos a finales del siglo XV. Recordemos también las beatas de San Pedro originado, como ya señalamos antes, por la idea del cura y capellán de la capilla de San Pedro de la catedral, don Diego Fernández de Úbeda en 1482. Llegó incluso a redactar unas constituciones ${ }^{35}$ escritas en 1487, confirmadas por el arzobispo de Toledo, Bartolomé de Carranza en 1570. No desapareció y el hecho es que las beatas toman clausura con la regla de san Benito de Nursia en 1629. El paso definitivo tardará en producirse, llega con la reforma de las recoletas en 1652, entonces evolucionaron a la reforma recoleta, convirtiéndose en una de las dos únicas comunidades toledanas bajo dicha reforma. La otra será las recoletas bernardas de la Asunción, las primeras nacidas en aquel desarrollo reformista.

En resumen, todas las fundaciones han evolucionado a cenobios. En algunos casos, sus orígenes en beaterios preexistentes fueron para Toledo los más destacados entre el siglo XV y XVI; pero cabe una segunda opción, los conventos aparecidos en torno a las reformas de finales del siglo XVI. Es entonces cuando ha desaparecido el componente beato. Como resultado, en algunos casos hay claustros con una doble finalidad socio-

32 En el siglo XVII contamos con F. Pons Fuster, "Mujeres y espiritualidad: las Beatas valencianas del siglo XVII", Revista de Historia Moderna: Anales de la Universidad de Alicante, 10 (1991), pp. 71-96. El autor es un gran conocedor de la vida regular valenciana. Autores para el área andaluza son Soledad Gómez Navarro, Felisa Cerrato Mateos y María del Mar Graña Cid. Cabe recordar otros autores como B. Echaniz Martínez, E Alemán Ruiz y A Corada Alonso. Sus estudios se referenciarán en la bibliografía final.

33 La figura y personalidad de Santa Teresa ha motivado multitud de publicaciones, y en especial en el centenario de su nacimiento celebrado en 2015. J. García Rojo (ed.), Teresa de Jesús. V Centenario de su nacimiento: historia, literatura y pensamiento. Actas del congreso Internacional Teresiano, Salamanca, Diputación Provincial de Salamanca, 2015; M. Sánchez Monge y T. Álvarez, Cultura y mujer en el siglo XVI: el caso de Santa Teresa de Jesús, Ávila, 2006.

34 F. Villarreal y Águila, La Thebaida en poblado. El convento de la Inmaculada Concepción Capuchina, 1686. 35 Merced a su testamento, en 1489, las beatas recibieron importantes beneficios. Archivo del Convento [A.C.P.C.N.S], libro becerro, fol.343. 
religiosa. ¿Podemos considerarlos modelos fundacionales? Bien pudiera ser que según las necesidades de cada siglo evidenciemos una tipología fundacional u otra, unos rasgos peculiares o individualidades. De todo ello se deriva una vida claustral muy diversa. El elemento clave del siglo XVI en la vida religiosa femenina desde entonces es la reforma del Concilio de Trento, la clausura estricta para las monjas. Los intentos de implantar la clausura estricta presentan un proceso que no era cerrado, ni tampoco coherente en algunos momentos.

Las fuertes desavenencias y desobediencias fueron, en su momento, tratadas de ocultar, e incluso de silenciar. En otros momentos se iniciaron procesos de ajuste. El tema de la imposición de la clausura no termina con Trento, pero ha generado dos visiones diferentes y, desde luego, opuestas: para unos historiadores, la liberación; para otros, la exigencia de cumplimiento. En Toledo existen datos como el del convento que estudiaremos a continuación, resultado de los enfrentamientos con los superiores.

\section{TRENTO, LOS RECHAZOS A LA CLAUSURA Y LAS INTROMISIONES INTERNAS. EL CASO DEL MONASTERIO DE SAN CLEMENTE}

La observancia de la clausura estricta entre las monjas de finales del siglo XVI, cuando el Concilio de Trento cambia los esquemas de la vivencia femenina en el convento, y en adelante es uno de los temas de análisis más interesantes. Pero no solamente en cuanto a la aplicación del voto estricto, sino en cómo se trataba de implantar. Hay que analizar también cuáles fueron otros aspectos de rechazo en otros elementos de la vida interna, elementos del día a día. Lo que abre la posibilidad de estudiar otras vías de oposición y que convierten a los conventos en centros en ebullición.

En general, el planteamiento de la historiografía centrada en la aplicación del Concilio de Trento y, en concreto, en el decreto sobre el voto claustral ha sido valorado por unanimidad como un triunfo indiscutible de efectividad. Pero es más que evidente que el estudio en profundidad de este aspecto se aleja mucho de esta visión. En cambio, como acertadamente la profesora Ángela Atienza, y otras investigadoras reflejan en sus trabajos, dentro del propio concilio la aplicación de la clausura estricta fue un tema verdaderamente discutible y discutido. Las divergencias en torno a la disciplina eran evidentes incluso entre los propios agentes presentes en él. Este aspecto ha sido en numerosas ocasiones soslayado, dándose por sentado cómo las políticas disciplinares fue seguido y aplicado de forma estricta. La disconformidad no solo existió dentro de los claustros, además existió por igual un rechazo social. Los abundantes textos de la época sobre el encerramiento parecen reiterar una idea central para la mujer, para ello la literatura religiosa y didáctica son una vía fundamental. El voto de clausura ${ }^{36}$ obligaba en dos sentidos con pena de doble pecado mortal para las monjas, sacrilegio contra este voto y desobediencia; pero con Trento era todavía más exigente, pues además de lo anterior, la maldición del que violara el voto era a todos los efectos eterna. Las cerraduras y el impedimento de entrada de personas externas a la comunidad claustral, además de muros reforzados, limitadas ventanas, etcétera, hacen del convento un muro casi impenetrable. Y, para que el efecto sea el deseado, ese hermetismo se inculca mediante una estricta espiritualidad unida a las creencias. $Y$ es evidente que la vida claustral encaja a las monjas en un ámbito cerrado, tanto interno como externo.

Las discordias internas en los cenobios y las resistencias a la clausura estricta son dos elementos que las fuentes documentales han obviado de forma reiterada. En su mayoría, las visitas anuales y las Reales Cédulas son las fuentes más adecuadas o las únicas. En los últimos años, el interés por exponer los desórdenes entre las monjas nos ha

36 Autoras norteamericanas y británicas han publicado sobre temáticas femeninas. 
procurado un nivel de información antes inexistente u obviada. Así, varios autores publican con gran acierto los casos localizados en diversas comunidades, como los publicados por Guillermo Nieva Ocampo para las ramas masculinas. En cambio, el foco de atención sobre las comunidades femeninas pueden seguirse en las publicaciones Ángela Atienza, Ernesto Mayor i Zaragoza ${ }^{37}$, Francisco Javier Lorenzo Pinar ${ }^{38}$, Mariló Vigil ${ }^{39}$, Emilio Callado Estela ${ }^{40}$, Magdalena de Pazzis Pi Corrales ${ }^{41}$, y seguramente olvido a otros.

Las vicisitudes que se vivieron en los claustros de Toledo para encauzar el cumplimiento de la clausura estricta es difícil de conocer por la escasez de fuentes, pero no por ello debió de ser inexistente, a juzgar por los datos que nos aporta una de las comunidades más antiguas de la ciudad, el monasterio de San Clemente ${ }^{42}$.

El monasterio de San Clemente se funda en el siglo XII bajo la obediencia benedictina, que en 1180 abandona para insertarse en la reforma cisterciense. Pero la etapa que nos interesa es justamente los datos aportados durante el reinado de Felipe II. A través de las reales cédulas y las referencias a las visitas anuales se constatan los rechazos y las dificultades que las monjas crean en la vida de la comunidad. El punto de partida está en la elección de la abadesa ${ }^{43}$, pero partiendo del oficio y la vida interna se comprueba cuáles eran las resistencias a la clausura y cómo hay que hacer hincapié en otros dos aspectos esenciales de la vida regular, los cambios institucionales y la economía monástica. Recordemos cómo el Concilio de Trento $^{44}$ y los concilios postridentinos, para el caso de

37 E. Zaragoza i Pascual, "Procesos de reforma contra la abadesa de Lobios y la priora de Pesqueiras", Compostellanum, 41 (1996), pp. 357-389. Del mismo autor "Proceso de reforma contra los abades de San Salvador de Albeos (1499)", El Museo de Pontevedra, 51 (1997), pp. 561-590. También es de interés del autor, "La reforma y jurisdicción del monasterio de monjas cistercienses de San Quince de Valladolid (Siglos XVXVII)", Cistercium, 253 (2009), pp. 171-186. El autor se centra en comunidades cistercienses y benedictinas. 38 Lorenzo Pinar, "Monjas disidentes. Las resistencias a la clausura en Zamora tras el Concilio de Trento", en Disidencias y exilios en la España Moderna. Actas de la IV Reunión Científica de la Asociación Española de Historia Moderna, Alicante, Universidad de Alicante, 1997, vol. II, pp. 71-80.

39 Suyo: "Conformismo y rebeldía en los conventos femeninos de los siglos XVI y XVII", en Religiosidad femenina: expectativas y realidades (ss. VIII-XVIII), Madrid, Almudayna, 1991, pp. 165-185.

40 En Valencia, los conventos de Santa María Magdalena y Nuestra Señora de Belén de la ciudad. Su artículo: "Mujeres, reforma y resistencia. Las dominicas valencianas de Santa María Magdalena en los siglos XVI y XVII", en La vida cotidiana y la sociabilidad de los dominicos: entre el convento y las misiones (siglos XVI-XVII-XVIII), Arpegio, 2001, pp.73-103.

41 En el caso de la profesora Pazzis, "Existencia de una mujer: vivir el convento, sentir la reforma (siglos XVIXVII)", Tiempos Modernos, 20 (2010/1), pp 1-37.

42 El monasterio cuenta con un catálogo: C. Torroja Menéndez, Catálogo del archivo del Monasterio de San Clemente de Toledo (1141-1900), Toledo, IPIET, 1973. De J. C. Vizuete Mendoza, véase: "El Císter en Toledo fundación y exención del monasterio de San Clemente", Cistercium, 192 (1993), pp. 155-161. Temas relacionados con Trento, "'Dolor de corazón"'. Contrición, literatura espiritual y la formación de una sensibilidad religiosa postridentina", Vínculos de Historia, 4 (2015), pp. 106-124. También María Damián Yáñez Neira o Rafael Sánchez Domínguez.

43 L. Canabal Rodríguez, "Felipe II y su política religiosa: el convento de San Clemente de Toledo", en Felipe II (1527-1598): Europa y la Monarquía católica, Madrid, Parteluz, 1998, vol. III, pp. 139-158. El detonante de los problemas en Toledo, la elección de abadesa, se observa en otras comunidades, véase: M. C. Gómez García, "Los conflictos en la clausura femenina de la Málaga Moderna" en Disidencias y exilios en la España Moderna, Actas IV Reunión Científica de la Asociación Española de Historia Moderna, Alicante, Universidad de Alicante, 1997, vol. II, pp. 81-89.

44 Sobre Trento, I. Fernández Terricabras, Felipe Il y el clero secular: la aplicación del Concilio de Trento, Madrid, Sociedad Estatal para las Conmemoraciones de Carlos I y Felipe II, 2000. También C. Soriano Triguero, "Trento y el marco institucional de las órdenes religiosas en la Edad Moderna", Hispania Sacra, 52 (2000), pp. 479-493. 
Toledo fueron los concilios provinciales celebrados en la ciudad en $1565^{45}$ y 1582 . Caben puntualizar otros hechos clave: la redacción de breves y bulas que venían a complementar el Concilio, así la bula Militantes Ecclesiae del 17 de septiembre de 1565 o un breve Cum gravissimis de causis en los años siguientes, el 12 de diciembre de 1566. Este último fijaba la reforma de las religiosas claustrales de la orden franciscana, mientras en 1565 el Papa Pío IV (1559-1565) subrayaba los temas de reformas monásticas. Sin olvidarnos de los pasos fundamentales ocurridos con la bula Circa Pastoralis promulgada por Pío $V$ en $1566^{46}$, donde establecía que las monjas que habían profesado los votos perpetuos estarían obligadas a la clausura, pero no solo quedaba ahí, iba más allá, fijando su atención en la regla tercera, de forma que aquellas monjas terciarias deberían desde entonces profesar los votos solemnes para pasar de esa manera a formar parte de la vida de clausura.

El monasterio de San Clemente vive un período entre 1572 y 1598 lleno de problemáticas en torno a la clausura, que tiene como hemos dicho, su momento culminante en el enfrentamiento por la elección de abadesa, primero en su elección entre 1572 y 1577, y posteriormente, en un segundo momento, con una reelección del oficio entre 1585 y $1591^{47}$. A lo largo de todas las reales cédulas, las monjas tratan de escapar de innumerables problemas y enfrentarse con otros que no eran nuevos, pero habían llegado a encauzarse. Tres son las figuras centrales en el abadiado, Beatriz Pacheco de Castro, Aldonza de Navarra y María de Rojas. En el exterior el rey Felipe II y el gobernador del arzobispado en cada momento, en especial Sancho Busto de Villegas. El período trienal que establece la normativa en el oficio de abadesa es uno de los elementos del que parten los enfrentamientos internos de las monjas. Como en casi todas las situaciones, intramuros había dos facciones y la obligación de cumplir con la normativa creada en el Concilio de Trento tuvo una fuerte influencia en los componentes internos y en la economía conventual. El número de monjas capaces de ser sostenidas crean una fuerte atmósfera de control de las rentas, siendo las cuentas, el patrimonio y la dote otro de los objetivos no resueltos con anterioridad a Trento. Es por tanto obvio, cómo a través de los cambios institucionales, la economía comunitaria y la clausura se conforman un triángulo, que se puso de manifiesto en los enfrentamientos por disconformidad en estos tres factores de control a la comunidad femenina, partiendo inicialmente de los rechazos a las abadesas elegidas desde fuera e impuestas de forma efectiva por el propio rey, quien tenía su patronato.

Nuestros primeros datos nos acercan a la elección de abadesa, diez años después del fin del concilio tridentino, en 1572. La entonces abadesa Beatriz Pacheco de Castro es rechazada por la comunidad, pues había estado de priora con anterioridad en la casa de beatas de la reina en el mismo Toledo. Su mal gobierno y actuaciones dentro tanto de la casa de beatas, como en el monasterio de San Clemente, al terminar su oficio de abadesa -a lo largo de los tres años establecidos- dejaba una situación de gran desagrado hacía ella, que las monjas querían saliera de la comunidad, algo que ella no tenía intención de hacer. De manera que fue el propio gobernador del Arzobispado, don Sancho Busto de Villegas, quien se encargará por orden real de hacerla salir de la comunidad; no sin el

45 El estudio de este concilio puede seguirse en J. L. Santos Díez. y A. Fernández Collado.

46 No olvidemos que, además de la bula Circa Pastoralis, el propio papa Pío V tuvo mayor rigor en la bula de 1570, Decori et honestitati.

47 L. Canabal Rodríguez, "La aplicación de Trento en la vida regular: el convento femenino de San Clemente de Toledo", Cistercium, 232 (2003), pp. 571-596; M. L. Bueno Domínguez, "Las mujeres de Santa María de las Dueñas de Zamora. La realidad humana", El cristianismo medieval, Madrid, Almudayna, 1991, pp. 231245. En la cédula de 1572, del 29 de agosto, Archivo Histórico Nacional [desde ahora A.H.N], Consejos, libro 1 , fol. $187-187 \mathrm{v}$. 
descontento de la propia Beatriz a juzgar por la real cédula del 29 de agosto de 1572: "[...] queja y pretensión que doña Beatriz de Castro monja de Sanct Clemente de essa ciudad tiene". Y este hecho fue el primer paso, pues con su salida llegaba el proceso de elección del oficio, con un nuevo desencuentro entre las monjas, ya que el propio rey lo reafirma cuando leemos en el mismo documento algo más abajo: "[...] y podrá ser que con la nueva election que ha de haber de abadesa de aquella casa sea sosiegue lo qual procurareis de manera que cesen sus quejas y la negociación que sobre esto tratais". Es en ese proceso cuando vuelven a ponerse de manifiesto los disgustos y negativas entre la comunidad por la nueva elección de abadesa, después de una visita.

Y por qué tanta dificultad, el motivo es que unido a esta nueva abadesa está restaurar la observancia claustral y el voto de clausura estricta. Es tan complicado y se encuentran con tanto rechazo, que el gobernador y el rey deciden traer de fuera a la siguiente abadesa de San Clemente, se valora la posibilidad de traer una de las dos monjas del monasterio de las Huelgas de Valladolid. Al final, la elección recae en doña Aldonza de Navarra ${ }^{48}$ que llegaba desde la ciudad vallisoletana. Pero, ante los disgustos creados en Toledo, se les impone la nueva abadesa y, además, quedaba especificado en el documento que el corregidor de Toledo estaría presente a la entrada del monasterio a la llegada de la nueva abadesa de San Clemente para recibirla: "reciban y admitan por tal y sigan la orden que ella y nos les dieredes en el gobierno del dicho monasterio ${ }^{49 "}$. La nueva abadesa, impuesta y con unas intenciones conocidas por las monjas, tendrá en los primeros momentos de su llegada la obligación de sanear la economía del monasterio y realizar algunas reparaciones ${ }^{50}$.

No obstante, la oposición a la abadesa no cesaba, pues gracias a otra Real Cédula sabemos que una gran parte de la comunidad no había aceptado a Aldonza de Navarra y lo exponen en una carta que dirigen al rey. Y así se lo hace saber al gobernador Sancho Busto de Villegas en $1575^{51}$. Ante tamaña intromisión de las monjas en una situación que ellas deben asumir, hay varias opiniones y soluciones. El rey se muestra conciliador, pero tanto el corregidor de la ciudad como el gobernador piensan que la mejor forma de establecer el orden dentro del monasterio es la excomunión ${ }^{52}$. Finalmente, la solución fue sacar de la comunidad a las ocho monjas reacias a la imposición de la abadesa, y con ella del modelo claustral que traía consigo, de las doce que se oponen. Además de hacerlas salir del monasterio, al menos, que sepamos fue temporalmente, se las reparte entre cuatro monasterios para que no estén juntas. Sabemos que Ana Mejía, Inés de Rivera, Isabel de Guzmán y María de Zalama, salieron a Yepes; un segundo grupo, marcha a Talavera, Isabel Manuel y María de Rojas; el tercer grupo, sale hacia Ocaña al monasterio de San Miguel de Ocaña, en esta ocasión una sola monja, Ana de Cervatos; y la anterior abadesa Beatriz Pacheco de Castro fue traslada a Guadalajara ${ }^{53}$. En las cédulas de Felipe ${ }{ }^{54}$ averiguamos cómo en primer instancia el rey se mostró comprensivo en cierto grado. Desde entonces, su primera valoración y solución fue sacar a todas las monjas del monasterio y así hacer llegar nuevas. Claramente contaba con un grupo nuevo de monjas que no se opusieran a

48 Aldonza de Navarra era hermana de uno de los maestrescuelas de la catedral de Toledo, Juan de Navarra, y su padre fue copero de Fernando el Católico, y descienden de los reyes de Navarra.

49 A.H.N, Consejos, libro 1, fol. 190-190v. La Real cédula está fechada en Madrid el 4 de septiembre de 1572. 50 En dicho proceso la abadesa llega a solicitar al Rey un empréstito de 1.000 ducados A.H.N, Consejos, libro 1, fols. 211, 215-216. Del 28 de noviembre y el 31 de diciembre de 1572.

51 Así podemos leerlo en A.H.N, Consejos, libro 1, fol.343v-344.

52 F. J. Lorenzo Pinar, "Monjas disidentes....", p, 72.

53 Lo sabemos por una real cédula A.H.N, Consejos, libro 1, fol. 358.

54 Así lo expuso en 1575, en una real cédula del 26 de septiembre, A.H.N, Clero, libro 1, fol.362. 
la reforma y la clausura, leales a las obligaciones nacidas de Trento. Una solución que se aprecia en otros monasterios ya en el siglo XV, así lo vemos en otros monasterios de la orden gracias a los estudios del Ernest Zaragoza Pascual ${ }^{55}$. Pero hay más, el rey pone el foco de atención sobre una de las monjas más destacadas o por decirlo así, la que el rey estima cabeza de los rechazos, María de Rojas, hermana de un canónigo de la catedral de Toledo, Rodrigo de Ávalos.

Aquellas ocho monjas, el grupo más reacio y enfrentado a la reforma tridentina en San Clemente, pero no es el caso. Sabemos que hubo otras monjas no tan proclives a los enfrentamientos, pero también resistentes a la situación impuesta por el rey a las cuales en cambio no se las trasladó. De su número no tenemos constancia, ni el rey lo concreta, pues afirmaba en 1576 "[...] las demás que parece son las que excedieron menos y han dado más muestras de enmienda y arrepentimiento vuelvan al dicho monasterio de San Clemente ${ }^{56 "}$.

Felipe II lleva a cabo este proceso de conformidad con sus ideas de reforma de la vida claustral que tenía desde sus primeros años de príncipe. No olvidemos que, si bien fue una reacción habitual en la forma de obligar e inculcar la reforma y la clausura, el propio rey siempre con intención de comprobar cómo eran aquellas mujeres y qué problemas podrían aparecer posteriormente, encargaba informes al gobernador sobre ellas, sobre todo las más enfrentadas y fuertes a la imposición. Y así se los hacen llegar ${ }^{57}$.

Volvieron al monasterio, primero dos de ellas: Ana Mejía e Isabel Manuel. Sin embargo, no fue por el perdón real, más al contrario la motivación era económica, y simplemente sería por un período de treinta días para volver a su exilio. La reacción de final fue de parte del rey encargar el regreso al monasterio de las que estaban castigadas en abril de 1577, "que vuelvan por ahora a su monasterio y así lo podreis ordenar".

Al mismo tiempo de producirse estos acontecimientos, el trienio anual de Aldonza de Navarra que tanto había costado instalar como abadesa de San Clemente, abría otra etapa en el abadiado. Pero, ¿por qué terminaba esa etapa? En principio, parece que la mala salud de Aldonza de Navarra es la motivación más señalada. Ahora bien, ¿pudiera ser que el rechazo diario o al menos de alguna parte de las monjas hizo su efecto? Las fuentes no sirven para explicarnos este hecho y otros muchos, aunque solo vemos de manera parcial o tangencial. Hay algo más, entre las candidatas para sustituir a la impuesta Aldonza de Navarra aparecen nombres ya señalados: Isabel de Guzmán, María de Rojas o Inés de Rivera en el año 1576. Cómo puede ser que de las trasladadas luego a otras comunidades por su rebeldía las veamos como candidatas a tan destacado oficio. Por fin, la elegida Isabel de Guzmán reflejaba un cierto grado de unanimidad entre las monjas, pero no sería simplemente de ellas, dos personas habían asesorado e informado al Rey Prudente de la conveniencia de poner a esta monja en el oficio, tanto la anterior abadesa Aldonza de Navarra como el propio gobernador del arzobispado, Sancho Busto de Villegas, que en ese año de 1576 había cesado en su cargo. Así, el nuevo gobernador Diego de Castilla, ya

55 La problemática de la congregación claustral en Toledo, E. Zaragoza Pascual, "La congregación benedictina claustral toledana”, Boletín de la Institución Fernán González, 214 (1997), pp. 47-60. Reseñar a Soledad Gómez Navarro, y María Luisa Candau Chacón, un trabajo de F. Núñez Roldán, "Gobierno, convivencia y tensiones en una comunidad conventual femenino. San Leandro de Sevilla, 1612", en M. L. López Guadalupe Muñoz y J. J. Iglesias Rodríguez (coords.), Realidades conflictivas: Andalucía y América en la España del Barroco, Sevilla, Universidad de Sevilla, 2012, pp. 299-318.

56 En A.H.N, Consejos, libro 1, fols. 436v-438. También lo encontramos en el Archivo del Monasterio de Santo Domingo el Antiguo, desde ahora A.M.S.D.A, legajo 3/59. El monasterio de Santo Domingo el Antiguo, conserva estos documentos por un hecho de gran interés, el cese de Sancho Busto de Villegas.

57 A.H.N, Consejos, libro 1, fols. 361-362. 
desde 1576 hasta la fecha señalada de 1577 fue el encargado de realizar la visita canónica al monasterio en la primavera de este último año. Las cualidades de Isabel de Guzmán la convierten en la mejor candidata.

Profundicemos algo más en la elección de Aldonza de Navarra. El rey impone al gobernador no aceptar la posibilidad de renuncia de aquella, el rey exponía a las demás que quedaron en el monasterio a que hicieran penitencia. Así el castigo a las que no salieron de la comunidad fue

Sobre que me ha escrito con instrucción que mire por ella y le respondo lo que vereis por la copia de su carta que va aquí y hecho esto nombraseis hasta doce monjas las que constare que han dado más ocasión, que fueren más culpadas en lo que en este negocio ha pasado. Y la primera será la hermana de don Rodrigo de Avalos, canónigo de esta Iglesia, y dareis orden que se lleven luego a diferentes monasterios de su orden de los que hay en este arzobispado que están sujetos a vos como os pareciere con que no quede ninguna es esa ciudad ni en monasterios de otras órdenes para que hagan penitencia, y no sé si convendría que por ahora se saquen de los monasterios a donde se llevaren otras en su lugar para traer al de San clemente, esto veris vos y avisareis de lo que acerca de ello os pareciere antes de ponerlo en ejecución. Y además de esto ordenareis que entre las demás monjas que quedaren, se entienda las que estuvieren más culpadas y se incluyan en su monasterio hasta veinte de ellas para que hagan penitencia, con lo cual creo que las demás se desengañaran de que no han de salir con su intención y que se redujeran a la obediencia que deben y, cuando esto no bastase se podrá dar orden para sacar todas las demás de ese monasterio sin que quede ninguna y se lleven a otros de su orden y traigan otras en su lugar para que por este medio se extirpen las malas costumbres que se han introducido por lo pasado en esa casa y se reforme en todo como más convenga al servicio de Dios y observancia de su orden porque esto mismo se ha usado con monjas de monasterios de ella y de otras de este Reino .. después de idas las monjas y sosegadas las que quedaren se podrá ejecutar la reelección hecha o hacerla de nuevo de la dicha doña Aldonza ${ }^{58}$.

A pesar de las peticiones de recogimiento del rey, las monjas han sido, al parecer, encauzadas de nuevo a la reforma, no sin un alto nivel de oposición que curiosamente volverá a producirse en las siguientes décadas dentro de la misma comunidad y, de nuevo por el oficio de abadesa.

Nueva elección en la década de los años ochenta del siglo XVI, vuelven a aparecer de nuevo. Y nuevamente a través de la elección de abadesa. Las problemáticas subyacen en torno al objetivo para la vida regular femenina en Trento. La abadesa de san Clemente en 1585, doña María de Rojas, tiene cuestionada su reelección. Finalizado el trienio de la abadesa, y con la visita canónica, serán sesenta y dos monjas las encargadas de votar para la elección o reelección. Pero la reelección de la abadesa simboliza una nueva ruptura dentro de la comunidad. De las sesenta y dos monjas que debían votar, solo lo hicieron cuarenta y dos, el resto, veinte de ellas no ejercitaron su deber. Aquellas que no habían votado, solicitaban que se llevara a cabo la visita canónica encargada al obispo don Diego de la Calzada. Conviene hacer una puntualización, los problemas que trae consigo este rechazo por parte de un grupo de monjas, no viene dado por una oposición a la abadesa del momento. La base de su negativa está en el modelo de elección de la abadesa, la normativa aplicada en Trento por la elección del oficio. Las obligaciones, la duración y la elección en el oficio mantienen un sistema normativo con unos requisitos del Concilio de Trento fueron recopilados. Al mismo tiempo, las constituciones de la Orden fueron aclarando y controlando 
estos problemas, además de todas las problemáticas creadas en la vida interna.

Los límites con los cuales se encontraron las monjas que habían votado en contra de la reelección son bien claros, el obispo señaló que sería la propia doña María de Rojas la elegida, y en caso de no estar de acuerdo con el proceso de elección, deberían elevar sus quejas en un plazo de tres días. Será cuando las quejas se plantearan en varias cuestiones: primero, y como ya citamos, para la elección del oficio, era necesario hacer antes la visita canónica ${ }^{59}$; segundo, no estaba establecida la continuidad en el oficio más de tres trienios, como era el caso de doña María, por tanto no podía ser reelegida; tercera, todas las monjas debían votar, y en ese proceso, no todas lo hicieron y el voto debía ser secreto.

Para terminar, no se cumplía con el motu propio según lo cual y en cumplimiento de una normativa del papa Gregorio XII, la reelección de abadesa en el Císter estaba prohibida. Así que a la vista de todos los incumplimientos que se aprecian en este caso, el rechazo estaba bien fundado. En segundo lugar, caben añadir unos cargos que las monjas indicaban en contra de doña María, de los cuales al final fue absuelta, la demostración de las vulneraciones en la votación del oficio es indudable.

Las contradicciones observadas y cuestionadas de una parte de las monjas las lleva a plantear quejas por medio de súplicas incluso al Consejo Real. A pesar de las quejas y de que se lleva a cabo la visita exigida por las monjas, realizada por el licenciado Bautista Vélez, miembro del consejo del cardenal de Toledo, el licenciado Serrano y por último, el doctor Pedro de Carvajal ${ }^{60}$. Dejan bien claro las dificultades, las bases de las quejas y la necesidad de aclarar estos problemas.

De nuevo, al terminar la visita se llevó a cabo la elección de la abadesa, pero estos tres miembros nombrados para ello vuelven a incumplir un hecho. No es que no pudiera ser reelegida, estaba inhabilitada según los establecimientos normativos. Pero, además, ellos no estuvieron presentes, un hecho inexcusable. Por lo tanto, la elección de abadesa había infringido demasiadas normativas, las tridentinas, y las de la Orden y constituciones. El pleito llegó a las más altas instancias, el Consejo Real, el arzobispado e incluso al papa que había redactado un breve. Lamentablemente no consta en todo el documento la fecha de cada documento, se inicia en 1585 y se alargó hasta $1591^{61}$. Se incluyen las cuentas de gastos de los viajes del mayordomo del monasterio Francisco Sánchez Hurtado ${ }^{62}$, para solucionar todo el proceso. Las quejas llegaron hasta el papado.

Los desórdenes y las discordias son las situaciones más destacadas. Hay que hacer hincapié en otras problemáticas y actuaciones, resultado de la aplicación de los decretos tridentinos, en especial los temas económicos y, unido a ello, el número de monjas de la comunidad y la dote. Unos elementos de control que fueron en buena medida objetivo de oposición y una fuerte implicación del monarca a finales del siglo XVI. Para lograr una comunidad estable con un equilibrio entre el número de monjas y el sostenimiento adecuado de las mismas, es uno de los aspectos tratados en Trento para las comunidades femeninas especialmente. Y así lo recuerda en numerosas ocasiones Felipe II, como se aprecia en

59 Quedó establecido en el concilio tridentino para la vida regular. Volvía a quedar establecida en el Concilio Provincial de Toledo, en 1582. Véase A. Fernández Collado.

60 El Doctor Carvajal es sobrino del arzobispo de Toledo desde 1598, García de Loaysa y Girón. Pedro de Carvajal, deán de la catedral desde 1592, si bien no fue hasta el año siguiente cuando tomo posesión del oficio.

61 Esta complicada elección de abadesa está un legajo de la comunidad, A.C.S.C, legajo 96, nº 7, folios 2041. No hemos localizado más información sobre este pleito en la sección de Consejos de Archivo Histórico Nacional.

62 Sobre las comunidades cistercienses en otras áreas, para Andalucía Felisa Cerrato Mateos. 
la Real Cédula de 1576, pues era conocido que no podrían entrar nuevas novicias "hasta que las que hay queden en el número que mereciere convenir ${ }^{63 "}$ ". La necesidad de la dote es para toda comunidad regular femenina esencial y la lectura de las reales cédulas nos advierten de la dureza con que el rey recordaba su función y necesidad. Tres elementos, el cupo de monjas estaba en directa conexión con la dotación económica esencial para el sosteniendo de la casa conventual; $y$, es una necesidad muy unida al tercer componente, la dote. El tema económico estaba bien reglamentado en dos breves entre las décadas de los sesenta y setenta del siglo. Nos referimos al breve De statu Ecclesiarum del 7 de octubre de 1568 y tres años más tarde, su reiteración del 1 de octubre de 1571.

De lo que no cabe duda es que ello será importante la economía. Y es así, si nos fijamos en una situación creada por la falta de dote en la entrada de una de las hijas del mayordomo del monasterio. Francisco Gaitán deseaba que dos de sus hijas fueran recibidas para monjas de coro, y así se produjo, ninguna de las dos aportó la dote, solamente el ajuar. Recibidas en 1566 Ana de Cervatos y María Gaitán entraron por expreso deseo de la comunidad, debido a un favor hacía su padre. En torno a este mayordomo, las dudas en cuanto a su gestión del patrimonio monástico eran evidentes para el rey. El problema de la carencia de dote de sus hijas lo reivindicaría hacia 1577 el propio rey, que obligará al monasterio a recibir la dote ${ }^{64}$. Francisco Gaitán sería cuestionado en su gestión económica, lo que le hizo perder su función administrativa, llegando a enriquecerse personalmente. Las deudas del monasterio, la mala gestión de su mayordomo y de las abadesas incidieron de forma indudable entre los aspectos, que el rey no dejaría al azar.

El Rey Prudente buscó de manera efectiva la aplicación de Trento entre las monjas se impulsará, controlando así el recogimiento, la reglamentación interna y la economía monástica. Tenemos constancia de que de todos los decretos tridentinos, los más problemáticos para su aplicación fueron los centrados en la vida interna, justamente los que aparecen en las reales cédulas. Todas estas medidas que la jerarquía y el Consejo Real intentaban inculcar fueron rechazadas por parte de las monjas, o al menos, intentaron de manera activa negar este control y hermetismo a las que se las abocaba por diversas vías ${ }^{65}$.

\section{CONCLUSIONES}

Desde el Medievo, la coexistencia de las fundaciones de vida regular y las nacidas de forma independiente, con un grado de heterodoxia fuera de las órdenes afincadas en la vida religiosa en emparedamientos y beaterios, han dado lugar a una pluralidad de gran valor para comprender un modo de vida religiosa externa a la Iglesia. Pero al mismo tiempo, y en especial a partir del siglo XIII, la aportación de las agrupaciones de beatas o las beatas independientes producen una alteración, que propicia un complicado modelo de instaurarse dentro de la Iglesia.

Aquella situación vislumbra un modelo de religiosidad femenina. Las beatas y mujeres laicas tomaban voto de pobreza y castidad, pero no voto de clausura. Las jerarquías eclesiásticas y la monarquía trataron de asimilarlas con bastante éxito. Fueron muy escasos los ejemplos de beaterios que no quedaron bajo el influjo de órdenes mendicantes, de las reformas bajomedievales y del Barroco. Las beatas y monjas toledanas reafirmaron su

63 A.C.S.D El Antiguo, legajo 3/59.

64 A.M.S.C, legajo 3/61. La documentación puede seguirse también en A.M.S.C, legajo 39, $n^{\circ}$ 3,4, 5, 6; Legajo 39, n³6 y 49. Ana de Cervatos y Gaitán fue abadesa que sepamos desde 1622 hasta 1629.

65 Es analizada en el siglo XVIII, F. J. García Pérez, "La resistencia a la clausura en los monasterios femeninos de Mallorca durante el siglo XVIII", Espacio, Tiempo y Forma. Serie IV. Historia Moderna, 30 (2017), pp. 211232. 
nivel de independencia por diversos medios, rechazaron uniones conventuales, abrieron los caminos de la reclamación a sus jerarquías superiores llegando hasta el Consejo Real y al Papado. E igualmente infringieron las normas internas reclamando su papel en la vida claustral y de beaterio como les fue posible. Defendieron con ahínco sus intereses y sus particularidades incluso frente a Trento.

Con la llegada del concilio tridentino, los cambios en la vida claustral desde 1563 y, más en concreto todavía, desde 1566 con la bula Circa pastoralis, abren un proceso de polémicas en torno a ellas. Monjas cuyo conformismo inicial se alterna con las reivindicaciones, posibles fisuras y rebeldías en un periodo de autoafirmación que, desde mi punto de vista, está presente a partir de la implantación de los beaterios en la Baja Edad Media, pues los beaterios no fueron simplemente el reflejo de las carencias económicas para entrar en la vida regular, son mucho más. ¿Fueron, tal vez, el comienzo?.

Toledo es fuente de gran número de beaterios, luego de monjas terciarias, y finalmente de conventos efectivos. Algunos beaterios lograron fijarse en la vida religiosa de la ciudad, sin pasar a institucionalizarse. Con el siglo XVI, e incluso antes, las monjas mantuvieron acciones de ruptura y resistencia por varias vías. En el caso de Toledo, hemos comprobado y concluido que estos enfrentamientos llegaran a formar casi un modelo. Mediante tres cuestiones: no simplemente sería el rechazo a la clausura, que sería la idea principal, siempre teniendo en cuenta dos tipos de clausura, la interna y la externa; el segundo punto a considerar es la economía comunitaria, valorando el patrimonio y ajustando a ello el número de miembros de la comunidad; y, por último, los cambios institucionales. Lo más importante es la posibilidad de ahondar a través de las vistas canónicas y la figura de las abadesas en todo este mundo de desobediencia. En buena medida, serán las abadesas y las prioras los oficios visibles de las comunidades, además de la vía para controlar las comunidades.

El análisis nos permite afirmar un hecho cierto, tenemos ante nosotros un campo de investigación amplio, si podemos aprovechar las fuentes, que poco a poco van aflorando. Así podremos comprobar las diversas posturas de resistencia femenina en los conventos, iniciadas desde los primeros pasos de los beaterios. Indagar en la conflictividad de la vida regular femenina. La documentación nos muestra, beatas o monjas legitimadas para ello, no habían hecho voto de clausura, patrimonios extensos y de gran valor, con interés por mantenerlos porque pretendían gestionarlos, pero no sólo sus bienes sino también su vida religiosa.

\section{BIBLIOGRAFÍA}

Abad Pérez, A., Soledad Sonora. Convento de San Antonio de Padua, Talavera-Toledo, 1980.

Alemán Ruiz, E., Inicios de la clausura femenina en Gran Canaria: el Monasterio de la Concepción, 1592-1634, Las Palmas de Gran Canaria, Universidad de Las Palmas de Gran Canaria, 2000.

Álvarez, T., Cultura y mujer en el siglo XVI: el caso de Santa Teresa de Jesús, Ávila, 2006. Atienza, A., "De beaterios a conventos: nuevas perspectivas sobre el mundo de las beatas en la España Moderna", Historia Social, 57 (2007), pp. 145-168.

Atienza, A., "Los límites de la obediencia en el mundo conventual femenino en la Edad Moderna: políticas de clausura en la Corona de Aragón, siglo XVII", Studia Histórica, Historia Moderna, 40/1 (2018), pp. 125-157.

Atienza López, A., Tiempo de conventos. Una historia social de las fundaciones en la España Moderna, Madrid, Marcial Pons, 2008.

Burrieza Sánchez, J., (ed.), El alma de las mujeres. Ámbitos de espiritualidad femenina en 
la modernidad (siglos XVI-XVII), Valladolid, Universidad de Valladolid, 2015.

Burrieza Sánchez, J., "La percepción jesuítica de la mujer (siglos XVI- XVIII)", Investigaciones Históricas, 25 (2005), pp. 85-116.

Bueno, M. L., "Las mujeres de Santa María de las Dueñas de Zamora. La realidad humana", El cristianismo medieval, Madrid, Almudayna, 1991, pp. 231-245.

Callado Estela, E., "Mujeres, reforma y resistencia. Las dominicas valencianas de Santa María Magdalena en los siglos XVI y XVII", en La vida cotidiana y la sociabilidad de los dominicos: entre el convento y las misiones (s. XVI-XVII-XVIII), Arpegio, 2013, pp. 73-103.

Canabal Rodríguez, L., "La aplicación de Trento en la vida regular: el convento femenino de San Clemente de Toledo", Cistercium, 232 (2003), pp 571-596.

Canabal Rodríguez, L., "Beaterio y convento. Origen, evolución y desarrollo de las comunidades regulare de la Orden Franciscana de Toledo", en Congreso Internacional.

El Franciscanismo: identidad y poder, Baeza, Priego de Córdoba, 2015, pp. 317-330.

Canabal Rodríguez, L., "Clausura en el siglo XVII: el convento dominicano de Jesús y María en Toledo", Toletana. Cuestiones de Teología e Historia, 14 (2006) pp. 137-160.

Canabal Rodríguez, L., "Las comunidades religiosas femeninas de Toledo. Implantación y características generales de su patrimonio fundacional (siglos XII- XVII)", Toletana. Cuestiones de Teología e Historia, 9 (2003), pp. 287-322.

Canabal Rodríguez, L., Los conventos femeninos en Toledo. Siglos XII- XVI, Madrid, Universidad Complutense, 1997, (tesis doctoral inédita).

Canabal Rodríguez, L., "Constituciones de una comunidad concepcionista. El monasterio de la Concepción de Toledo", en I Congreso Internacional del Monacato femenino en España, Portugal y América (1492-1992), León, Universidad de León, 1993, vol. 3, pp. 203-211.

Canabal Rodríguez, L. "Conversos toledanos en un espacio de poder, la Catedral Primada. Don Francisco Álvarez de Toledo, canónigo y mecenas (ss.XV-XVI)", Espacio, Tiempo y Forma, Serie IV, Historia Moderna, 24 (2011), pp. 13-32.

Canabal Rodríguez, L., "Don Francisco Álvarez de Toledo, maestrescuela de la catedral y benefactor del convento de San Miguel de los Ángeles de Toledo", Archivo IberoAmericano, 66 (2006) pp. 269-290.

Canabal Rodríguez, L., "Dos reinados y dos cortes. Una dama portuguesa en la corte castellana. Doña Beatriz de Silva y Meneses (1447-1491)", en Reinas e infantas en los reinos medievales ibéricos. Contribuciones para su estudio, Santiago, Universidad de Santiago, 2015, pp. 361-385.

Canabal Rodríguez, L., "Educación femenina en la Edad Moderna: constituciones del Colegio de Doncellas Nobles de Nuestra Señora de los Remedios, Toledo (siglo XVI)", Estudios Humanísticos. Historia, 12 (2013), pp. 127-154.

Canabal Rodríguez, L., "La fe de san Francisco y su voz. Continuidad y diversidad fundacional de las ramas femeninas en la Ciudad Imperial (siglos XIII- XVII)", Sémata: Ciencias sociais e humanidades, 26 (2014), pp. 193-219.

Canabal Rodríguez, L., "Felipe II y su política religiosa: el convento de San Clemente de Toledo", en Felipe II (1527-1598): Europa y la Monarquía católica, Madrid, Parteluz, 1998, vol. III, pp. 139-158.

Canabal Rodríguez, L., "Fundación y dotación de una comunidad franciscana femenina por un linaje converso. El convento de San Miguel de los Ángeles en el Toledo del siglo XV", Archivo Ibero-Americano, año 68, 261 (2008) pp. 529-544.

Canabal Rodríguez, L., "Isabel Vázquez. Sirvienta de doña Beatriz de Silva", Archivo Iberoamericano, 63/ 246 (2002), pp. 713-723. 
Canabal Rodríguez, L., "Libros y liturgia en la Orden de Santiago: el monasterio femenino de Santa Fe (Toledo, 1566)", Revista de Órdenes Militares, 7 (2013), pp. 205-225.

Canabal Rodríguez, L., "Mujer y reclusión en el siglo XVI. Fundación y estatutos de la Casa de Nuestra Señora del Refugio en Toledo", Tempus. Revista en Historia General, 2 (2015), pp. 1-38.

Canabal Rodríguez, L., "La Orden Militar de Santiago en Toledo: una visita el convento de Santa Fe en 1566", en I Congreso Internacional Las Órdenes Militares en la Península Ibérica, Cuenca, Universidad de Castilla- La Mancha, 2000, vol. II, pp. 2279-2291.

Canabal Rodríguez, L., "Las religiosas agustinas en Toledo. Medios de adquisición patrimonial, (siglos XIV-XVII)", Archivo Agustiniano, 83, n. 201 (1999), pp. 137-159.

Canabal Rodríguez, L., "La reforma franciscana entre las monjas del siglo XV. La nueva orden de la Inmaculada Concepción", en Congreso Internacional. El Franciscanismo: identidad y poder, Baeza y Priego de Córdoba, 2015, pp. 395-420.

Candau Chacón, M. L., "De la ‘vida particular' a la 'vida común': monjas díscolas en la Sevilla Barroca. "Por una parte me llamaba Dios; por otra yo seguía el mundo", Homenaje a D. Antonio Domínguez Ortiz, 2008, vol. II, pp. 127-156.

Ceballos, A., "Ellas y ellos. Un análisis de la fundación del convento de Santo Tomás de Villanueva de Granada en clave de género", Chronica Nova, 41 (2015), pp. 145-168.

Cerrato Mateos, F., El Císter en Córdoba. Historia de una clausura, Córdoba, Universidad de Córdoba, 2005.

Corada Alonso, A., Un beaterio en la Castilla del siglo XVIII. Vida y muerte de San Lázaro de Aguilar de Campoo, Palencia, Institución Tello Téllez de Meneses, 2015.

Cortés Alonso, A. L., y López-Guadalupe Muñoz, M. L., (eds.), La Iglesia española en la Edad Moderna. Balance historiográfico y perspectivas, Homenaje al archivero D. Pedro Rubio Merino, Córdoba, Abada, 2006.

Díez Rastrilla, J., Mariana de San José. Fundación del monasterio de Valladolid (16061610), Madrid, BAC, 2015.

Duque Fernández da Silva, J. F., Doña Beatriz de Silva. Vida e obra de una mulher forte, Labryrinthus, Maia, 2008.

Eduardo Franco, J., Sánchez Alves, J., (Coords.), Santa Beatriz da Silva. Uma estrela para novos rumbos, Cascais, Principia, 2013.

Echaniz, B., "Una aproximación a la espiritual femenina en el Alicante de principios del siglo XVII", Feminismo/s, 20 (2012), pp. 275-295.

Echaniz Martínez, B., Las Monjas de la Sangre. Historias de vida en la Modernidad alicantina, Tesis doctoral, Universidad de Alicante, 2017.

Fernández Collado, A., La catedral de Toledo en el siglo XVI. Vida, arte y personas, Toledo, Diputación Provincial de Toledo, 1999.

García Oro, J., Portela, M. J., "La reforma de la vida religiosa en España y Portugal de la vida religiosa durante la Reforma", Archivo Iberoamericano, 62, n. 243 (2002), pp. 455-618.

García Oro, J., Cisneros y la reforma del clero español en tiempo de los Reyes Católicos, Madrid, 1971.

García Rojo, J. (ed.), Teresa de Jesús. V Centenario de su nacimiento: historia, literatura y pensamiento. Actas del congreso Internacional Teresiano, Salamanca, Diputación Provincial de Salamanca, 2015.

Gómez García, M. C., "Los conflictos en la clausura femenina de la Málaga Moderna" en Disidencias y exilios en la España Moderna, Actas IV Reunión Científica de la Asociación Española de Historia Moderna, vol. II, Alicante, Universidad de Alicante, 1997, pp. 81-89. 
Gómez Navarro, S., "De rejas adentro: monjas y religiosas en la España Moderna. Una historia de diferencias en la igualdad", Revista de Historia Moderna. Revista de la Universidad de Alicante, 29 (2011), pp. 205-277.

Graña Cid, M. M., Beatriz de Silva (ca. 1426-ca 1491), Madrid, Ediciones del Orto, 2004.

Guerrero M. D., y Álvarez, M. A., "Documentación medieval de Santa Eufemia de Cozuelos en el Mss 13.063 de la Biblioteca Nacional", Cuadernos de Estudios Medievales y Ciencias y Técnicas Historiográficas, 17 (1993), pp. 281-334.

Gutiérrez, E., Beata Beatriz de Silva y origen de la Orden de la Purísima Concepción, Valladolid, Server Cuesta, 1967.

Gutiérrez, E., Santa Beatriz de Silva e Historia de la Orden de la Concepción de Toledo en sus primeros años (1484-1511), Casa madre, Toledo, Aldecoa, Burgos, 1988.

Hernández Cabrera, M. S., "La celda del convento, una habitación propia. La vivencia de la clausura en la comunidad de dominicas de Montesión", Duoda: Revista de Estudios Feministas, 22 (2002), pp. 19-40.

Lorenzo Pinar, F. J., Beatas y mancebas, Zamora, Semuret, 1995.

Lorenzo, F. J., "Monjas disidentes. Las resistencias a la clausura en Zamora tras el Concilio de Trento", en Disidencias y exilios en la España Moderna. Actas de la IV Reunión Científica de la Asociación Española de Historia Moderna, Alicante, Universidad de Alicante, 1997, vol. II, pp. 71-80.

Martínez Ruiz, E. (dir.), El peso de la Iglesia Cuatro siglos de órdenes religiosas en España, Madrid, Actas, 2004.

Martínez Caviró, B., "Juana de Castilla fundadora del monasterio de Jesús y María", Beresit, II (1998), pp. 23-36.

Meseguer, J., "Primeras constituciones de las franciscanas concepcionistas", Archivo Iberoamericano, 25, 100 (1965), pp. 361-389.

Muñoz, A.," Las expresiones femeninas del monacato y la devoción: reclusas, monjas, freiras y beatas", en Mujeres en silencio: el Monacato femenino en la España Medieval, Palencia, 2017, pp. 41-70.

Muñoz Fernández, A., Acciones e intenciones de mujeres en la vida religiosa de los siglos XV y XVI, Madrid, Comunidad de Madrid, 1995.

Núñez Roldán, F., "Gobierno, convivencia y tensiones en una comunidad conventual femenina. San Leandro de Sevilla, 1612", Realidades conflictivas. Andalucía y América en la España del Barroco, Sevilla, Universidad de Sevilla, 2012, pp. 299-318.

Pazzis, M. de, "Existencia de una mujer: vivir el convento, sentir la reforma (siglos XVIXVII)", Tiempos Modernos, 20 (2010/1), pp. 1-37.

Pons Fuster, F., "Mujeres y espiritualidad: las Beatas valencianas del siglo XVII", Revista de Historia Moderna: Anales de la Universidad de Alicante, 10 (1991), pp. 71-96.

Salazar, P., Crónica e historia de la fundación y progreso de la Provincia de Castilla el bienaventurado padre San Francisco, Libro VII, Cap. XVIII, Madrid, 1612, p. 459.

Sánchez Monge, M., "Es tiempo de caminar". Santa Teresa de Jesús, maestra de la experiencia de Dios, Madrid, Biblioteca de Autores Cristianos, 2015.

Santos Vaquero, A., El Cardenal Silíceo y el Colegio de Doncellas Nobles de Toledo, Toledo, Ledoira, 2017.

Sastre, E., "La condición jurídica de beatas y beaterios. Introducción y textos, 1139-1917" Anthologica Annua, 43 (1996), pp. 287-586.

Serrano, E., "El patrocinio nobiliario de la vida en común: el beaterio dominicano del Espíritu Santo de Toledo", Territorio, sociedad y poder: revista de estudios medievales, 4 (2009), pp. 227-237. 
Serrano, E., "Piedad, nobleza y reforma. La fundación del monasterio de la Madre de Dios en Toledo (1483)", Archivo Dominicano: Anuario, 33 (2012), pp. 213-237.

Serrano Rodríguez, E., Toledo y los dominicos en la época medieval. Instituciones, economía y sociedad, Cuenca, Universidad de Castilla- La Mancha, 2014,

Vargas Martínez, A., La Querella de las mujeres. Tratados hispánicos en defensa de las mujeres (siglo XV), Madrid, Fundamentos, 2016.

Villarreal y Águila, F., La Thebaida en poblado. El convento de la Inmaculada Concepción Capuchina, 1686.

Vinyoles, T., "La princesa ermitaña, Eilonor de'Urgell", Anuario de Estudios Medievales, 44/1 (2014), pp. 349-377.

Vizuete, J. C., "El Císter en Toledo fundación y exención del monasterio de San Clemente", Cistercium, 192 (1993), pp. 155-161.

Zaragoza i Pascual, E., "Procesos de reforma contra la abadesa de Lobios y la priora de Pesqueiras", Compostellanum, 41 (1996), pp. 357-389.

Zaragoza i Pascual, E., "Proceso de reforma contra los abades de San Salvador de Albeos (1499)", El Museo de Pontevedra, 51 (1997), pp. 561-590.

Zaragoza i Pascual, E., "La reforma y jurisdicción del monasterio de monjas cistercienses de San Quince de Valladolid (Siglos XV-XVII)", Cistercium, 253 (2009), pp. 171-186. 